\title{
RESTITUIÇÃO DE TRIBUTO INCONSTITUCIONAL
}

\author{
DISSERTAÇÃO DE MESTRADO \\ Orientador: Prof. Dr. Paulo de Barros Carvalho
}

FACULDADE DE DiREITO

UniversidAde DE SÃo PAULO

SÃo PAULO

2014 


\section{RESUMO}

O presente trabalho debruça-se sobre a relação jurídica em que a Fazenda Pública tem obrigação de restituir valores indevidamente recolhidos pelo contribuinte a título de tributo, uma vez que tais pagamentos foram embasados em lei declarada inconstitucional pelo Poder Judiciário.

Tendo em vista que a validade é inerente às normas jurídicas, confundindo-se, portanto, com a sua existência, demonstra-se que a natureza tributária e o regime jurídico tributário regem a relação de restituição de tributos inconstitucionais.

Dando continuidade, todos os momentos para a edificação da relação de restituição de tributos inconstitucionais, desde o seu nascimento até a sua extinção, são abordados neste estudo, por meio de análise que subdivide em momentos lógicos o fenômeno jurídico em questão. Assim, inicialmente aborda-se o procedimento de transformação do pagamento devido em pagamento indevido, leia-se, o controle de constitucionalidade das leis. Dada a constituição do pagamento indevido por linguagem jurídica competente, configurado está o critério material da relação jurídica de indébito, entre Fisco e contribuinte, pela qual as quantias indevidamente pagas devem ser restituídas. Porém, não só aquilo que foi recolhido como se tributo fosse deve ser restituído, mas também quaisquer acréscimos patrimoniais cuja validade tenha sido igualmente fulminada pela declaração de inconstitucionalidade. A via eleita para o conhecimento e satisfação do direito do contribuinte pode ser administrativa ou judicial. Por sua vez, o momento lógico seguinte é a extinção da relação jurídica sob estudo, a qual ocorrerá pelo advento da decadência, prescrição, compensação, restituição administrativa ou pagamento de precatórios.

Por fim, estuda-se a possível reabertura da discussão entre Poder Público e contribuinte, por meio de ação rescisória pautada em declaração de inconstitucionalidade que atinge a coisa julgada entre as partes, sendo legítimo ao contribuinte reaver quantias indevidamente pagas mesmo sob o manto da res iudicata.

\section{Palavras-chave}

Restituição de tributo; repetição de indébito; tributo inconstitucional. 


\section{RESUMÉ}

Ce travail se concentre sur la relation juridique où le Trésor Public a l'obligation de rembourser des impôts indûment payés par le contribuable, étant donné que ces paiements étaient fondés sur une loi déclarée inconstitutionnelle par le Pouvoir Judiciaire.

En tenant compte que la validité est inhérente à des règles juridiques, c'est-à-dire, que la validité des normes s'identifie avec son existence, on conclut que la nature fiscale et le régime fiscal règissent la relation de remboursement des impôts inconstitutionnels.

D'ailleurs, on essaie d'étudier la relation juridique, depuis sa naissance jusqu'à son extinction, par une analyse qui partage le phénomène juridique en moments logiques. Ainsi, d'abord on analyse la procédure de transformation des paiements dus en paiements indus, c'est à dire, le contrôle de la constitutionnalité de la loi. Une fois reconnue le paiement indu d'impôt, par un langage juridique compétent, le critère matériel de la relation juridique de l'indu entre l'État et le contribuable existe et par conséquent les valeurs indûment versées doivent être restituées. Cependant, ce n'est pas seulement les impôts qui ont été collectés qui doivent être remboursés. Mais aussi tout ajouts (les amendes et les intérêts) dont la validité a été également frappée par la déclaration d'inconstitutionnalité. Le contribuable a deux axes à choisir pour la reconnaissance et pour avoir la satisfaction du remboursement des taxes inconstitutionnelles: la voie administrative ou la voie judiciaire. La prochaine étape de la relation juridique est son extinction, qui aura lieu par l'avènement de la déchéance, la prescription, la compensation, le remboursement administratif ou le remboursement judiciaire.

Finalement, on verra que la discussion entre État et contribuable peut être reprise par une action de résiliation, guidée par la déclaration d'inconstitutionnalité, qui atteint la chose jugée entre les parties. Donc, dans ce cas là, les contribuables ont le droit a la restitution des montants indûment versés au titre d'impôt.

\section{MOTS-CLÉS}

Remboursement d impôt; répétition de l'indu; déclaration d'inconstitutionnalité. 


\section{INTRODUÇÃO}

Sumário: a. Tema a ser desenvolvido e suas limitações. b. Justificativa da escolha e da importância do tema. c. Metodologia a ser utilizada.

\section{a. Tema a ser desenvolvido e suas limitações}

No presente trabalho, buscar-se-á abordar o tema da restituição de tributos inconstitucionais em sua amplitude, abrangendo as questões teóricas e práticas que o circundam.

Não seria apressado afirmar que o grande objetivo da pesquisa ora apresentada é equalizar o instituto da restituição de tributos inconstitucionais com o direito positivo tributário brasileiro. Isto porque este último não tratou de forma clara e suficiente de muitos pontos relevantes sobre o assunto, de modo que dúvidas nunca cessam de acometer o espírito dos juristas que se deparam com problemas atinentes à restituição de tributos inconstitucionais.

Neste sentido, e não obstante ao fato de o estudo apresentado versar sobre a matéria da restituição de tributos em geral, a todo o momento serão colocados em foco os atributos específicos da restituição de tributos inconstitucionais, justamente porque este constitui tema com particularidades que justificam sua apreciação em separado.

Para que fique clara a delimitação do tema a ser estudado, cumpre realçar que são diversas as razões pelas quais pode surgir o direito de o contribuinte reaver importâncias levadas aos Cofres Públicos. Ou, visualizando a relação jurídica em sentido oposto, são várias as razões que acarretam no dever do Estado de restituir o que indevidamente foi pago pelo contribuinte a título de tributo. Estas razões, 
inclusive, levam a doutrina a ensaiar diferentes formas de classificação de espécies dentro do gênero da devolução de tributos, utilizando distintos critérios para tanto. ${ }^{1}$

De fato, faz-se necessária uma classificação ${ }^{2}$ para que seja possível conhecer as características e peculiaridades jurídicas das figuras postas sob o manto da devolução de tributos. Com esse intuito, devem ser estabelecidos critérios, permitindo a separação entre classes, sempre levando em consideração o direito posto. ${ }^{3}$

O primeiro critério de classificação aplicável à matéria da devolução de tributos, para a separação do tema proposto, consiste no cumprimento ou não dos fundamentos mediatos (constitucionais) e imediatos (legais) de validade jurídica pela lei instituidora da exação tributária. Caso ambos os fundamentos forem cumpridos, vale dizer, se lei instituidora de um imposto estiver conforme a Constituição, tanto formal quanto materialmente, bem como o autolançamento/lançamento ${ }^{4}$ tributário cumpra os ditames da lei, ter-se-á um imposto devido. A seu turno, se a lei que institui o dever de o sujeito passivo pagar um imposto for contrária à Constituição, ou o autolançamento/lançamento tributário referente ao imposto desrespeitar a lei, advirá a figura do imposto indevido.

Essa distinção entre tributos devidos e indevidos levou a doutrina do direito alienígena, em face da legislação posta em países como na Itália, Alemanha e Espanha, a trabalhar com a diferenciação da nomenclatura entre restituição e reembolso. Enquanto a primeira expressão corresponde à devolução de ingressos indevidos, a segunda se relaciona com a devolução de ingressos devidos. ${ }^{5}$

1 Há a classificação bipartida, adotada na Alemanha; a tripartida, proposta pela jurista espanhol Corral Guerrero; e a quadripartida, adotada por Ricardo Lobo Torres, que a divide em: (i) repetição de indébito; (ii) restituição do indébito a causa superveniente; (iii) restituição de tributo a título de incentivo fiscal; e (iv) restituição de Empréstimo Compulsório (TORRES, Ricardo Lobo. Restituição de Tributos. Rio de Janeiro: Forense, 1983, p. 6).

2 Sobre a importância da teoria das classes, deve-se ter em mente que o direito é constituído por linguagem, e, ao utilizar a linguagem, atribuem-se nomes aos entes do mundo do dever ser. Dentro dos nomes podem caber um ou mais indivíduos e seus predicados, de sorte que os nomes são classes dentro das quais elementos se encaixam. Advertindo que a classe não se encontra na realidade física, mas sim na construção intelectiva, tem-se que "classe é o âmbito de aplicação de um conceito, sua conotação é a totalidade dos requisitos que delimitam este conceito, e sua denotação são todos os objetos que cabem no âmbito do conceito". (CARVALHO, Aurora Tomazini. Curso de Teoria Geral do Direito. São Paulo: Noeses. 2009, p. 309-310).

3 Paulo Ayres Barreto, evidenciando este método, ensina que "descrever o ordenamento jurídico, com o objetivo de conferir-lhe feições sistêmicas, com caráter científico, é tarefa que exige, a todo instante, a formulação de conceitos e a elaboração de classificações" (Contribuições: regime jurídico, destinação e controle. São Paulo: Noeses, 2006, p. 46-47).

4 Entende-se como autolançamento a norma individual e concreta expedida pelos contribuintes nos tributos sujeitos ao lançamento por homologação, constituindo o crédito tributário.

5 Cf. Fernandes, Luis Dias. Repetição de indébito tributário - o inconstitucional artigo 166 do CTN. Rio de Janeiro: Renovar, 2002, p. 6. 
No Brasil, contudo, o sistema jurídico não traçou expressamente a distinção entre restituição e reembolso, ${ }^{6}$ de modo que a separação é meramente doutrinária, porém válida, à medida que institui expressões distintas para fenômenos que realmente possuem contornos jurídicos que merecem diferenciação.

Pois bem, apesar de se tratar de assunto de grande importância para o direito, não é objeto deste trabalho o simples reembolso de tributo devido. ${ }^{7}$ Desse modo, no decorrer da dissertação evitar-se-á o uso do vocábulo reembolso de tributo, tendo em vista a preocupação estritamente com o fenômeno dos tributos indevidos, porque inconstitucionais e sua consequente devolução.

Registre-se, neste ponto, que a matéria dos tributos indevidos se destaca em relação à dos tributos devidos, porque se trata de situação mais frequente e regulada, e que, por conseguinte, atrai maiores esforços doutrinários, como observou Corral Guerrero. $^{8}$

Mas, de qualquer forma, é importante que fique clara a distinção entre devolução de tributos devidos e restituição de tributos indevidos, feita nos apontamentos abaixo.

Quanto à devolução de tributos devidos, trata-se de hipótese em que o contribuinte realiza o pagamento de determinado tributo, sendo este ato jurídico e a lei que o embasa totalmente compatíveis com os ditames constitucionais e infraconstitucionais do sistema tributário. Contudo, o desenho jurídico da exação tributária, que deu origem ao referido pagamento, determina a posterior devolução dos montantes recolhidos ao Erário. É possível visualizar esta espécie de situação, por exemplo, no empréstimo compulsório (artigo 148 da Constituição e artigo 15 do Código Tributário Nacional), ${ }^{9}$ em que é expressamente determinada pela lei a

6 O que podemos encontrar no direito brasileiro é a figura do "ressarcimento tributário, "que se constitui na obrigação da Fazenda Pública em pagar ao contribuinte valores decorrentes de créditos oriundos de determinados mecanismos de não cumulatividade tributária ou de créditos decorrentes de incentivos fiscais específicos. O ressarcimento fiscal, diferentemente da repetição de indébito, não decorre de erro ou ilegalidade, mas de obrigação inerente ao regime jurídico de certos tributos ou de certas modalidades de incentivos fiscais. Não há, desse modo, em seu regime jurídico, recolhimento indevido ou a maior, ou, como diz Rodrigo Petry, 'o ressarcimento é um regime jurídico-tributário diferenciado, voltado para outras finalidades que não a recuperação de tributos pagos indevidamente". (MARINS, James. O Direito Processual Tributário. 5. ed. São Paulo: Dialética, 2010, p. 307).

7 Na visão de Marcelo Fortes de Cerqueira, o reembolso de tributos devidos é matéria que não interessa ao direito tributário. Sua índole é financeira ou administrativa (CERQUEIRA, Marcelo Fortes. Repetição de Indébito Tributário. São Paulo: Max Limonad. 2000. p. 275-276).

8 El Derecho del contribuyente a la devolución de impuestos (introducción a una teoría general). Madrid: Revista de Derecho Privado, 1977, p. 211.

9 “Art. 148. A União, mediante lei complementar, poderá instituir empréstimos compulsórios: 
necessidade de estabelecimento de prazo para o empréstimo e as condições de seu resgate. Igualmente sob a rubrica da devolução de tributos devidos, aparecem as devoluções de benefícios fiscais, ou de valores decorrentes da aplicação da sistemática da não cumulatividade dos impostos sobre o consumo. ${ }^{10}$ Essa última hipótese deve ser claramente apartada da restituição de tributos indevidos, haja vista que em ambas as situações são utilizados institutos com a mesma nomenclatura, mas que não se confundem: crédito decorrente de pagamento de indébito não é crédito atribuído e disciplinado pela Constituição para a realização do princípio da não cumulatividade, bem como compensação de tributos indevidos não caracteriza compensação de créditos decorrentes da não cumulatividade. ${ }^{11}$

Retomando a segunda classe decorrente desta inicial classificação proposta para a matéria, apresentam-se os já elencados tributos indevidos originadores do fenômeno da restituição tributária.

I - para atender a despesas extraordinárias, decorrentes de calamidade pública, de guerra externa ou sua iminência;

II - no caso de investimento público de caráter urgente e de relevante interesse nacional, observado o disposto no art. 150, III, "b".

Parágrafo único. A aplicação dos recursos provenientes de empréstimo compulsório será vinculada à despesa que fundamentou sua instituição.

$[\ldots]$

Art. 15. Somente a União, nos seguintes casos excepcionais, pode instituir empréstimos compulsórios:

I - guerra externa, ou sua iminência;

II - calamidade pública que exija auxílio federal impossível de atender com os recursos orçamentários disponíveis;

III - conjuntura que exija a absorção temporária de poder aquisitivo.

Parágrafo único. A lei fixará obrigatoriamente o prazo do empréstimo e as condições de seu resgate, observando, no que for aplicável, o disposto nesta Lei."

10 Sobre a questão do direito ao reembolso de crédito acumulado de ICMS, por exemplo, ver: CoÊLHo, Sacha Calmon Navarro; DERZI, Misabel Abreu Machado. ICMS - Direito ao Creditamento - Princípio da Não-Cumulatividade. Revista Dialética de Direito Tributário $\mathrm{n}^{\circ} 102$, Março - 2004, p. 141-156; CRUZ, Célio Rodrigues da. Manutenção e Transferência de Crédito de ICMS. Revista de Estudos Tributários, Ano XII - n 69 - Setembro/Outubro 2009, p. 7 - 17; DERZI, Misabel Abreu Machado. Aspectos Essenciais do ICMS como imposto de mercado. In: SCHOUERI, Luis Eduardo; ZiLveTI, Fernando Aurelio (Coord.). Estudos a Homenagem de Brandão Machado, São Paulo: Dialética, 1998. p. 116 - 142; TORRES, Ricardo Lobo. O princípio da não cumulatividade e o IVA no direito comparado. In: MARTINS, Ives Gandra da Silva (Coord.). $O$ princípio da não-cumulatividade, São Paulo: Revista dos Tribunais, 2004, p. 139-170; XAVIER, Alberto. Regime Constitucional das Isenções e Incentivos Fiscais às exportações: o caso do ICMS. Do Direito à utilização integral de Saldo acumulado de créditos de ICMS como corolário da imunidade das exportações. In: TORRES, Heleno Taveira (Coord.). Tratado de Direito Constitucional Tributário - Estudos em Homenagem a Paulo de Barros Carvalho. São Paulo: Saraiva, 2005, 11. ed. Rio de Janeiro: Editora Forense, 2006, p. 597-623.

11 Cf. BAleEIRo, Aliomar. Direito Tributário Brasileiro. 11. ed. Rio de Janeiro: Editora Forense, 2006, p. 891 e 892. 
São indevidos os tributos porque guardam algum vício no seu processo de positivação. ${ }^{12}$ Quer dizer, seja sua colocação na ordem jurídica (nomodinâmica), seja conteúdo normativo (nomoestática), é ou são imperfeitos. Situação desta sorte, conforme a nomenclatura ora adotada, enseja o nascimento do direito/dever da restituição dos tributos.

Como segundo critério de classificação, agora já efetuando um recorte dentro da classe da restituição de tributos indevidos, aparecerá o nível hierárquico na pirâmide jurídica em que se encontra o defeito do ato normativo: a constitucionalidade ou não da lei que institui o tributo.

Justamente como resultado dessa distinção exsurge, nitidamente desenhado, o tema do presente estudo, a restituição de tributos inconstitucionais, em oposição à restituição de tributos constitucionais. Cabe lembrar que estes últimos, os tributos constitucionais, também podem ser objeto de restituição por serem acometidos por vício de positivação em nível infraconstitucional, ou seja, por o lançamento ou autolançamento tributário desrespeitar as leis instituidoras do tributo, ser eivado de erro de fato, erro de direito ou qualquer outra nulidade. Tais hipóteses, contudo, não serão cotejadas neste trabalho. ${ }^{13}$

Evidenciado o lugar que ocupa o objeto da presente dissertação, propõe-se o seguinte desenho:

12 Sobre o processo de positivação no direito, ver item 2.1 .

13 Mas, para que se identifique aquilo que estará fora do objeto da pesquisa, prestam-se alguns esclarecimentos: a devolução de tributos recolhidos a maior do que o devido, ou por pessoa diferente da devida, por erro do próprio sujeito passivo da obrigação tributária no momento de realizar o pagamento, não será abordada neste estudo. É esta hipótese constante da classe da restituição de tributos constitucionais. Noutros termos, casos em que a norma geral e abstrata que institui a exação tributária não é eivada de qualquer vício, porém houve recolhimento de importâncias a título de tributo que não eram juridicamente devidas por simples erro do contribuinte quanto a elementos como alíquota, base de cálculo ou sujeito passivo da obrigação (artigo 165, inciso II do Código Tributário Nacional), não estarão sob nossa análise. Tampouco serão centro de atenção neste trabalho as circunstâncias em que resta incólume a validade da regramatriz de incidência tributária de um determinado tributo, mas que, em razão de sua imperatividade, for realizado pagamento pautado em ato administrativo de cobrança, lavrado pela Administração Tributária contendo qualquer vício de legalidade, já que estes não se enquadram na classe da restituição de tributos inconstitucionais. 


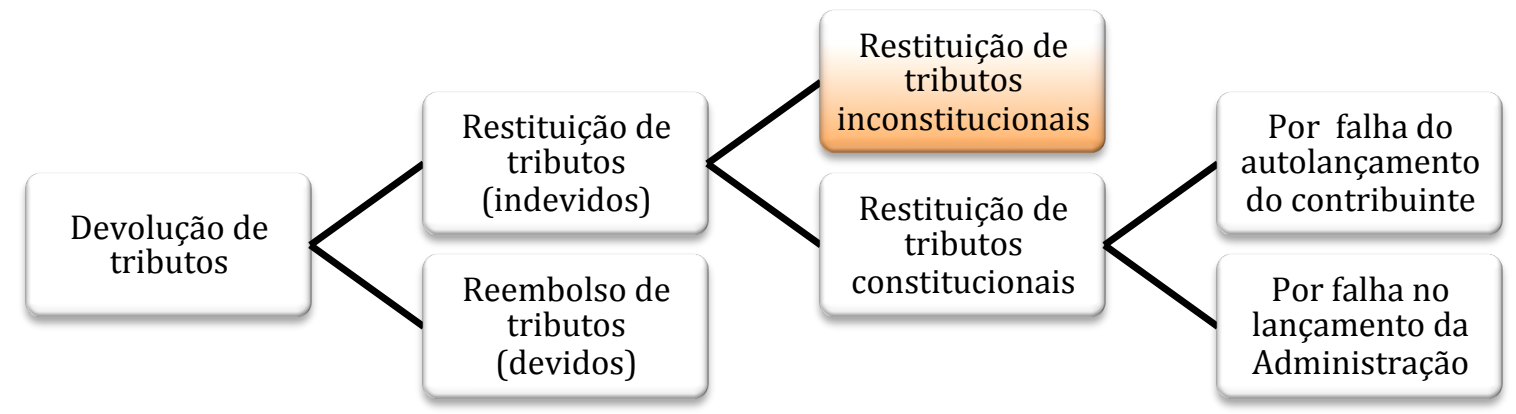

Em suma, depreende-se que é aqui estabelecida uma limitação temática que só compreende o estudo da natureza e da disciplina jurídica aplicáveis à restituição de tributos em função de incompatibilidades com o texto da Constituição. Todavia, tal limitação não faz com que sejam desconsiderados aspectos que, como destacado inicialmente, por serem comuns à sistemática da restituição de tributos de maneira geral, devam embasar a pesquisa.

Assim, cumpre realçar que neste trabalho serão averiguados todos os momentos lógicos estabelecidos pelo sistema jurídico para a restituição de indébito tributário por inconstitucionalidade, do seu nascimento a sua extinção.

\section{b. Justificativa da escolha e da importância do tema}

A restituição de tributos constitui, indubitavelmente, tema clássico do direito tributário brasileiro. Afinal, o direito tributário tem como principal escopo regular as relações entre o Estado e os contribuintes, de modo a suprir a necessidade de recursos daquele, enquanto preserva os direitos assegurados a estes.

Nesse contexto, o principal direito outorgado ao contribuinte é o de somente ser tributado nos estritos limites da lei, do contrário, terá direito de reaver o que lhe foi ilegitimamente retirado. Nasce, assim, a figura da restituição dos tributos.

Trata-se, verdadeiramente, de questão tradicional e abrangente no direito positivo, iniciando-se nas bases constitucionais do sistema tributário e terminando em regimes administrativos ou judiciais específicos para a realização do direito dos contribuintes. Da mesma forma, na ciência jurídica, a restituição de tributos alcança 
pontos profundos da Teoria Geral do Direito, ao mesmo tempo em que necessita de análise coerente no que tange aos meandros próprios do direito tributário.

Possivelmente seja esta abrangência que explique a escassa bibliografia sobre o tema, bem como o constante recorte metodológico que se verifica na doutrina ao estudá-lo.

Muito embora seja tema clássico e abrangente, a restituição de tributos tem se demonstrado atual e problemática. Isto porque dogmas jurídicos têm sido revistos, especialmente por inovações no direito constitucional, no direito processual e na jurisprudência das mais altas Cortes do Judiciário brasileiro, acarretando em consequências diretas na temática da restituição de indébitos tributários. ${ }^{14}$

Como exemplo atual das problemáticas apontadas, veja-se o caso da Contribuição ao Programa de Integração Social (PIS) e da Contribuição para o Financiamento da Seguridade Social (COFINS) sobre importações, que tiveram suas bases de cálculo recentemente julgadas inconstitucionais pelo Supremo Tribunal Federal, no Recurso Extraordinário 559.937/RS ${ }^{15}$. Dúvidas sobre o alcance dessa decisão em relação aos contribuintes, a possível modulação de efeitos, os valores que poderiam ser objeto de restituição, o prazo para os pedidos de devolução, a coisa

14 De fato, pode-se constatar, na seara do direito constitucional, por exemplo, que a tradicional distinção entre o controle de constitucionalidade principal (concentrado e abstrato) e o controle de constitucionalidade incidental (difuso e concreto) tem sofrido mitigações, em razão do advento de instrumentos como a repercussão geral (artigo 543-A do Código de Processo Civil) e a súmula vinculante (artigo 103-A da Constituição). Além disso, as manifestações do Supremo Tribunal Federal, sob influência do constitucionalismo europeu, mediante utilização de teorias como a da Transcendência dos Motivos Determinantes, têm aproximado as duas tradicionais modalidades de controle de constitucionalidade das leis. Isto porque a Teoria da Transcendência dos Motivos Determinantes preconiza que não somente a parte constante do dispositivo da decisão proferida pelo Tribunal Constitucional seja vinculante, mas também os motivos determinantes do julgamento, leia-se, a ratio decidendi. Como consequência da adoção dessa teoria, a declaração de inconstitucionalidade proferida no bojo de uma determinada ação direta de inconstitucionalidade poderá atingir outros atos normativos de conteúdo similar, pois o efeito vinculante se irradia para além do caso.

No que tange aos princípios constitucionais norteadores do direito tributário, também têm se mostrado palpitantes as inovações jurídicas da jurisdição constitucional. Veja-se a técnica da modulação de efeitos (artigo 27 da Lei ${ }^{\circ} 9.868$ de 10 de novembro de 1999) e as inequívocas alterações de jurisprudência dos Tribunais Superiores, diante do que se tornou imprescindível uma revisitação dos princípios da segurança jurídica e da legalidade. Em sede do direito processual, institutos preciosos, como a coisa julgada e a legitimidade de agir, têm sido colocados em xeque face aos problemas de inconstitucionalidade das leis. Por sua vez, as relações jurídicas continuativas e o direito de manejo da ação rescisória (artigo 485 do Código de Processo Civil) aparecem como questões muito mais maleáveis do que sólidas quando postas sob o prisma da inconstitucionalidade das leis. Todos estes pontos, além de tantos outros que serão enfrentados no decorrer deste estudo, têm repercussão inafastável no direito tributário, especialmente no que concerne à disciplina da restituição de tributos inconstitucionais.

15 BRASIL. Supremo Tribunal Federal. Recurso Extraordinário n. 559.937/RS. Relator: Ministro Dias Toffoli. Julgamento: 21 mar. 2003. Órgão Julgador: Tribunal Pleno. Publicação: DJe 04 abr. 2003. 
julgada em sentido contrário, dentre outras, demonstram como permanecem em aberto diversas questões sobre a restituição de tributos inconstitucionais.

Diante destas constatações, que culminaram na conclusão da relevância de um estudo atento e minucioso sobre o tema pelo Direito Tributário, foi possível observar que na literatura jurídica a matéria da restituição de tributos inconstitucionais não ganhou o devido apreço. ${ }^{16}$

Mas não é só. Observa-se que o fenômeno da edição de leis tributárias eivadas de inconstitucionalidade perdura no Direito brasileiro, ${ }^{17}$ de modo que a preocupação com o regime jurídico da restituição de tais tributos, com a segurança jurídica e com a responsabilidade do Estado se tornam indispensáveis, para pôr em evidência os direitos dos contribuintes e os deveres do Estado.

Ressalte-se, ainda, que, não obstante a aplicação da lei inconstitucional por atos de lançamento (artigo 142 do CTN) também acarrete no dever de restituir tributos, cada vez mais é dispensada a edição de atos normativos infralegais pela

16 Com efeito, são poucas as obras nacionais que tratam da repetição de indébito em sua forma ampla (ver TORRES, Ricardo Lobo. Restituição de Tributos. Rio de Janeiro: Forense, 1983; SAMPAIO, Carlos César de Oliveira. Restituição de Imposto. São Paulo: S.N., 1921; NeviAni, Tarcisio. $A$ restituição de tributos indevidos, seus problemas, suas incertezas. São Paulo: Resenha Tributária, 1983; CERQUeIRA, Marcelo Fortes de. Repetição de Indébito Tributário. São Paulo: Max Limonad. 2000), não obstante ser possível encontrar algumas coletâneas de artigos sobre a matéria (MACHADO, Hugo de Brito (Coord.). Repetição do Indébito e Compensação no Direito Tributário. São Paulo: Dialética; Fortaleza: Instituto Cearense de Estudos Tributário, 1999; CEZAROTI, Guilherme (Coord.). Repetição de Indébito Tributário. São Paulo: Quartier Latin, 2005; e MARTINS, Ives Gandra. In: Repetição do Indébito. (Coord.). Caderno de Pesquisas Tributárias $n^{\circ}$ 8. São Paulo: Centro de Estudos de Extensão Universitária e Editora Resenha Tributária, 1983). No mais, pode-se averiguar uma preocupação maior da doutrina com assuntos específicos dentro da matéria da restituição de tributos, especialmente sobre a repetição dos tributos ditos indiretos (FERNANDES, Luis Dias. Repetição de indébito tributário - o inconstitucional artigo 166 do CTN. Rio de Janeiro: Renovar, 2002; MACHADO SEGUNDO, Hugo de Brito. Repetição do Indébito Tributário Indireto: incoerências e contradições. São Paulo: Malheiros, 2011; MÖRSCHBÄCHER, José. Repetição do Indébito Tributário Indireto. São Paulo: Dialética, 1998).

Por sua vez, também pouco se preocuparam os juristas do direito tributário sobre as consequências da declaração de inconstitucionalidade das leis neste ramo jurídico (DALlAzEM, Dalton Luiz. Inconstitucionalidade e Tributo. São Paulo: Quartier Latin, 2010. LINS; Robson Maia. Controle de Constitucionalidade da Norma Tributária. São Paulo: Quartier Latin, 2005; e PIMENTA, Paulo Roberto Lyrio. Efeitos da Decisão de Inconstitucionalidade no Direito Tributário. São Paulo: Dialética, 2002).

Finalmente, sobre o pontual assunto que congrega ambas as matérias, quer dizer, o direito e a forma de restituição dos tributos declarados inconstitucionais - ao qual não foi dedicada legislação complementar expressa -, menor ainda foi o esforço jurídico científico (BERNO, Cheryl. Restituição de Tributo Inconstitucional. Curitiba: Juruá Editora. 2009; e GRECO, Marco Aurélio; PONTES, Helenilson Cunha. Inconstitucionalidade da lei tributária - repetição de indébito. São Paulo: Dialética, 2002).

17 Entre os anos de 1974 e 1997, existiram nada menos que vinte impostos, contribuições e taxas inconstitucionalmente cobrados. (Cf. MATTOS, Aroldo Gomes de. Repetição do Indébito, compensação e ação declaratória. In: MACHADO, Hugo de Brito (Coord.). Repetição do Indébito e Compensação no Direito Tributário, São Paulo: Dialética; Fortaleza: Instituto Cearense de Estudos Tributário, 1999, p. 47). 
Administração para atingir as condutas dos contribuintes, de modo que a lei tributária geral e abstrata apresenta influência direta em suas órbitas jurídicas.

De fato, quando uma lei traz ao sistema jurídico novo tributo ou dever instrumental $\left(113, \S 2^{\circ}\right.$ do $\left.\mathrm{CTN}\right),{ }^{18}$ traz concomitantemente a presunção de sua constitucionalidade. Tendo em vista que no Brasil a maioria das exações tributárias adota a sistemática do lançamento por homologação, diante da nova lei os contribuintes já passam a efetuar o recolhimento de tributos ou a cumprir os deveres instrumentais (registro, notas, guias, etc.). ${ }^{19}$ Vale dizer, em face de lei inconstitucional - ainda não declarada como tal pelo órgão jurisdicional competente e, portanto, ainda válida na ordem jurídica -, os cidadãos passarão a ditar suas condutas de acordo com os imperativos por ela impostos. Estes atos jurídicos caracterizarão pagamentos indevidos quando da declaração de inconstitucionalidade da lei com efeitos retroativos, acarretando no dever do Estado restituí-los. Afere-se, assim, a implicação direta, ou seja, sem a interposição de ato infralegal pela Administração, da lei inconstitucional no direito à restituição de tributos pagos indebitamente.

Ainda, o já avançado tempo da promulgação do Código Tributário Nacional, datado de 25 de outubro de 1966, recepcionado por Constituição que lhe sucedeu em 5 de outubro de 1988 com status de lei complementar, agrava as dúvidas sobre a matéria, pois parece não se amoldar com perfeição às suas especificidades, constitucionais e processuais, tornando ainda mais imperiosa uma nova apreciação interpretativa dos termos relativos à repetição de indébito.

São problemas como estes que fizeram crer ser valiosa contribuição acadêmica sobre o tema proposto, que, apesar de clássico, atualmente comporta releitura frente às novas disposições e interpretações do direito tributário brasileiro.

\section{c. Metodologia}

Simplesmente olhar e discorrer sobre o objeto observado, sem rigor algum, não constitui uma ciência, uma teoria. De fato, é imprescindível a existência de

\footnotetext{
18 “Artigo 113. A obrigação tributária é principal ou acessória. [...] $\S 2^{\circ}$ A obrigação acessória decorre da legislação tributária e tem por objeto as prestações, positivas ou negativas, nela previstas no interesse da arrecadação ou da fiscalização dos tributos."

19 Assim, as normas individuais e concretas são expedidas pelos próprios sujeitos passivos das obrigações tributárias, constituindo-as.
} 
linguagem precisa, rigor sintático e domínio informativo do objeto para a caracterização de uma pesquisa científica, como a que aqui se propõe.

Assim, para que os objetivos propostos neste trabalho sejam devidamente cumpridos, com o rigor exigido na consecução de pesquisas científicas, se faz necessária a adoção de um criterioso método de análise do objeto a ser estudado. Noutros termos, para que nasça o trabalho jurídico, deve ser utilizada uma precisa linha metodológica para a aproximação e estudo do direito positivo. ${ }^{20}$

Ocorre que, muito embora seja imprescindível a adoção de um método, diversos podem ser os métodos para uma pesquisa científica.

Com efeito, o Direito pode ser visto sob uma perspectiva histórica, levando-se em consideração o tempo e a evolução dos institutos jurídicos; ou sob um olhar sociológico, levando em conta elementos sociais e políticos; como também ser analisado num ponto de vista filosófico, político, comportamental ou sociopsicológico. $^{21}$

Neste trabalho acadêmico, entretanto, opta-se por uma análise jurídicodogmática do direito, de modo que se observará o tema da restituição de tributos inconstitucionais em relação ao ordenamento jurídico brasileiro, onde está inserido.

Mais especificamente, e já que se entende que é preciso transformar a linguagem ordinária em uma linguagem mais rigorosa, para poder-se falar que, em ciência jurídica, o método dogmático hermenêutico analítico é visto como o melhor caminho a ser tomado em nosso estudo. Hermenêutico porque, ao avaliar o direito positivo, não é possível fugir da interpretação. E analítico porque, ao interpretar, devem ser feitos cortes precisos no objeto sob análise. ${ }^{22}$

A Semiótica, a Teoria Geral do Direito e a própria Hermenêutica servem de técnicas para a implementação do método analítico. Por seu intermédio, é analisado o objeto de estudo, esgotando a avaliação da linguagem jurídica.

20 Neste sentido, constata-se que as teorias existem para que seja possível o conhecimento por meio da linguagem científica de determinados objetos. Possui o método, destarte, caráter instrumental e está sempre ligado às opções epistemológicas adotadas pelo intérprete, ao olhar para o seu objeto de análise.

21 Cf. ÁvilA, Humberto. Segurança Jurídica - entre permanência, mudança e realização no Direito Tributário. São Paulo: Malheiros, 2011, p. 76 e 77.

22 Ressalta-se que o método analítico consiste, em síntese, na decomposição de expressões complexas em expressões simples, para que uma melhor análise possa ser feita do objeto examinado. Mas não é só. Numa segunda etapa do método analítico, após a dissecação do objeto, ele passa a ser sistematizado e organizado no decorrer da sua interpretação, por onde se atribui sentido ao objeto. A filosofia analítica possui várias linhas, entre elas aquela advinda do Círculo do Viena. Foi o início desse estudo analítico, separando o elemento complexo em partes pequenas para facilitar seu conhecimento. 
De fato, com a Semiótica é possível a realização de um estudo analítico dos elementos formadores da linguagem jurídica, ou seja, as normas jurídicas. Isto se dá em função da própria finalidade da Semiótica, que é justamente o estudo das unidades representativas do discurso. Assim, o estudo da Semiótica, ou Teoria Geral dos Signos, implica na análise de três planos da linguagem. O primeiro deles é o plano sintático, no qual são estudadas as relações que se estabelecem entre os signos dentro da estrutura em que estão inseridos. Em segundo lugar aparece o plano semântico, onde a relação do signo com a realidade que representa, ou seja, seu significado, é colocada sob foco. Finalmente, o terceiro plano semiótico é o pragmático, cujo cerne é o efeito do signo na sociedade por ele atingida, "isto é, ao modo como os emissores e destinatários lidam com o signo no contexto comunicacional."23

Já sobre o recurso à Teoria Geral do Direito, lembre-se que direito posto é uno e indecomponível, como bem esclareceu Alfredo Augusto Becker. Contudo, o que se observa ao analisar o conteúdo jurídico apresentado pela Ciência do Direito é a tomada de determinados critérios para a dissecação do direito em ramos "autônomos", como o direito Civil, Administrativo, Penal, etc. Esta divisão, contudo, é meramente metodológica, sendo falso o problema da autonomia dos ramos do direito, como também salientou Becker. ${ }^{24}$

Pois bem. Diante desses ramos da Ciência do Direito, pode-se constatar a existência de institutos e conceitos que se repetem em diversas áreas, os quais podem ser tratados como pontos de intersecção. O apanhado desses pontos de intersecção para seu estudo disciplinado e inter-relacionado caracteriza a Teoria Geral do Direito, como mais uma das formas de diminuição de complexidades, própria do método analítico de estudo do direito.

Outrossim, cumpre realçar que será foco de análise com acuidade, além do direito posto (ordenamento jurídico), ${ }^{25}$ a doutrina jurídica (ciência do direito) e a

23 Carvalho, Aurora Tomazini de. Curso de Teoria Geral do Direito. São Paulo: Noeses, 2009, p. 157.

24 Em suas palavras: "pela simples razão de não poder existir regra jurídica independente da totalidade do sistema jurídico, a autonomia (no sentido de independência relativa) de qualquer ramo do Direito Positivo é sempre unicamente didática para, investigando-se os efeitos jurídicos resultantes da incidência de determinado número de regras jurídicas, descobrir a concatenação lógica que as reúne num grupo orgânico e que une este grupo à totalidade do sistema jurídico." (BECKER, Alfredo Augusto, Teoria do Direito Tributário. 4. ed. São Paulo: Marcial Pons, 2007, p. 33).

25 Necessário se faz ressaltar a diferença entre a doutrina, ou ciência do direito, e o ordenamento jurídico, ou direito positivo. A principal diferença a ser apontada entre o direito positivo e a ciência do direito é que o primeiro é formado por linguagem prescritiva, enquanto o segundo por linguagem descritiva, haja vista que tem por escopo a análise do direito posto, portanto seu objeto. 
jurisprudência acerca da matéria, especialmente dos Tribunais Superiores, vale dizer, o Supremo Tribunal Federal e o Superior Tribunal de Justiça. Afinal, apreciação desses meios se faz necessária para alcançar as conclusões satisfatórias, precisas e atuais que perquiridas neste estudo acadêmico.

Trilhando este caminho, será possível alcançar uma redução da vagueza do tema da restituição de tributos inconstitucionais, pela reflexão sobre as problemáticas que dele decorrem, trazendo com isso solução às questões que se propõem elucidar neste trabalho.

Mas não é só. Também podem ser salientadas as seguintes diferenciações: i) a ciência de direito é uma linguagem de sobrenível, ou sobrelinguagem, diferentemente do direito positivo; ii) a ciência do direito se vale da lógica apofântica (lógicas das ciências, alética ou clássica), enquanto o direito posto utiliza a lógica deôntica (lógica do dever ser, das normas); iii) as proposições traçadas pela ciência do direito têm como valências aplicáveis a verdade e a falsidade; por sua vez, no direito positivo, as normas jurídicas são passíveis de validade ou invalidade; e iv) por fim, quanto ao âmbito pragmático, temos que as normas do direito positivo se conduzem para as condutas materialmente (lembrando aqui o primordial objeto do direito, qual seja, a regulação das condutas interpessoais), ao passo que a ciência do direito serve à descrição analítica, estática e dinâmica, das normas. (CARvalho, Paulo de Barros. Curso de Direito Tributário. 22. ed. São Paulo: Saraiva, 2010, p. 35-36). 


\section{CONCLUSÕES}

Com o objetivo de compreender a relação de restituição de tributos inconstitucionais em sua integralidade, vale dizer, de seu nascimento até sua extinção, foi proposta a repartição do instituto em momentos lógicos e a busca de uma coerente aplicação das regras postas no ordenamento jurídico pátrio à matéria.

Assim, o presente estudo iniciou-se por breve análise da questão da validade das normas jurídicas.

Concluiu-se que o modelo que parece mais satisfatório para explicar o fenômeno é admitir que a validade é da essência das normas, de modo que a existência e a validade jurídica se confundem. Nesse sentido, a lei, uma vez inserida no sistema jurídico, é plenamente válida e eficaz, bem como os atos nela fundamentados. Somente com a introdução de outra norma no ordenamento jurídico, como aquela proferida pelo Poder Judiciário decretando a inconstitucionalidade de um ato normativo, com efeitos gerais e retroativos, é que se estará diante da invalidade da norma. Esta permite que atos formados com base na lei nula/inconstitucional/inválida sejam desfeitos, dentro dos limites impostos pelo próprio sistema jurídico.

Estabelecida tal premissa, percebeu-se que tanto a edição de leis inconstitucionais como a cobrança de tributos com base em tais leis tributárias inconstitucionais são atos ilícitos praticados pelo Poder Público. O primeiro constitui ilícito constitucional (edição de lei contrária aos dizeres da Constituição), enquanto o segundo caracteriza ilícito tributário (cobrança pelo Estado e consequente pagamento pelo contribuinte de tributo inválido). Lembrando que as normas jurídicas em sua feição completa são impreterivelmente dotadas de uma sanção em caso de descumprimento, aos citados atos ilícitos o ordenamento jurídico atrela as respectivas sanções: a declaração de inconstitucionalidade, com o objetivo de preservar a integralidade e coerência da ordem jurídica; e a restituição de tributos inconstitucionais, cuja função é conferir segurança jurídica e isonomia aos administrados.

Ainda com base no conceito de validade, foi definido que a natureza jurídica do instituto da restituição de tributos inconstitucionais é tributária, e, por conseguinte, o regime jurídico a ser aplicado a este instituto é aquele referente à matéria tributária. Isto porque, quando do pagamento da dívida fiscal, tratava-se de montante 
completamente válido perante o sistema jurídico, sendo que só posteriormente passou a ter a qualidade de indevido pela declaração de inconstitucionalidade. Ademais, o direito tributário cuida de tudo aquilo que direta ou indiretamente se relaciona com a relação jurídico-tributária, inclusive os ilícitos tributários. Nesse sentido, constata-se que a restituição de indébito está ontologicamente ligada à obrigação tributária, haja vista que aquela é a consequência do pagamento indevido, que nada mais é do que fato jurídico tributário, abarcado pela disciplina do Código Tributário Nacional. Corroborando este fato, observou-se que o Anteprojeto do CTN previa expressamente a hipótese de restituição de tributos inconstitucionais dentre os seus dispositivos. Tal hipótese expressa não permaneceu no texto aprovado do atual Código, pois a disciplina geral das situações que garantem a devolução de tributos indevidos já abarca os tributos inconstitucionais (artigo 165, inciso I).

$\mathrm{O}$ direito dos contribuintes a reaver tributos indevidamente levados aos cofres públicos, porque inconstitucionais, tem fundamento na própria Constituição, especialmente no princípio da legalidade, uma vez que a aplicação equivocada do ordenamento jurídico é suficiente para justificar a restituição de tributos. Ademais, os postulados da propriedade, igualdade, capacidade contributiva, equidade, justiça, segurança jurídica, moralidade, não confisco e responsabilidade civil do Estado por atos legislativos também lapidam o direito dos contribuintes a só serem tributados nos termos da Constituição. Todavia, o princípio da proibição do enriquecimento sem causa, típico do direito privado, não pode ser alçado como fundamento do direito à restituição de tributos inconstitucionais, pois não há que se falar em "causa", "vontade" ou "empobrecimento do contribuinte" no direito tributário, em que a estrita legalidade reina de maneira superior.

Em nível infraconstitucional, os artigos 165 a 169 do Código Tributário Nacional fundamentam tal direito, sendo, porém, certo que estes dispositivos não podem restringir a garantia dada constitucionalmente aos contribuintes de serem ressarcidos em caso de pagamento indevido de tributo.

Depois de percorrida toda essa trajetória no Primeiro Capítulo deste trabalho, o último ponto abordado antes de sua finalização foi a nomenclatura a ser utilizada para a relação jurídica sob estudo. Conclui-se que, para que seja precisa e compatível com os contornos do instituto, a terminologia que melhor se ajusta ao fenômeno ora estudado é restituição de tributos inconstitucionais. Afinal, a natureza jurídica desta relação é tributária, não havendo problema em qualificar o substantivo tributo com o 
adjetivo inconstitucional, assim como ocorre com legitimidade da expressão repetição de indébito. Aliás, entende-se que o jurista deve buscar precisão nos termos utilizados, mas não criar barreiras linguísticas para o estudo de fenômenos cuja nomenclatura bem representa objeto sob análise, ainda mais sendo expressão consagrada pelo direito para tanto.

Passando ao Segundo Capítulo, esforços foram dedicados para compreender a norma padrão que determina a relação de restituição de tributos inconstitucionais, afinal, como qualquer relação jurídica, a restituição de tributos inconstitucionais se baseia em uma norma geral e abstrata que determina que, na hipótese de serem cobrados e pagos tributos com base em leis incompatíveis com os ditames da Constituição, os valores recolhidos ao Erário deverão ser devolvidos ao contribuinte lesado. Contudo, antes que efetivamente nasça o direito à devolução, um procedimento intermediário de reconhecimento da invalidade da lei tributária deverá ocorrer, qual seja, o controle de constitucionalidade da lei. Uma vez concluído esse procedimento instrumental, restará devidamente declarada pela autoridade competente a inconstitucionalidade do ato normativo, ou seja, terá sido oficialmente retirado da ordem jurídica o fundamento legal dos pagamentos tributários. Com isso, os pagamentos antes qualificados pelo direito como devidos passam a ser indevidos, concedendo aos contribuintes a possibilidade de acionar a máquina estatal para requerer a expedição de normas individuais e concretas determinando que, em face dos recolhimentos indevidos (antecedente normativo), o Estado deve, agora, efetuar a devolução dessas quantias (consequente normativo).

A primeira via para o reconhecimento da inconstitucionalidade da lei tributária consiste no controle de constitucionalidade principal (concentrado e abstrato). As principais características dessa espécie de fiscalização de validade dos atos normativos são a eficácia erga omnes, o efeito ex tunc e vinculante da decisão alcançada pelo STF em ação direta. Como consequência desses elementos, a declaração de inconstitucionalidade faz com que a lei sancionada saia do conjunto de normas válidas. Mas não é só. Em razão destes mesmos efeitos jurídicos, retrooperantes e gerais, é que se torna possível que qualquer contribuinte, pagador da obrigação imposta pela lei contrária à Constituição, possa se beneficiar da declaração de inconstitucionalidade para o pleito da restituição do que foi indevidamente recolhido a título de tributo. 
Como segunda forma de reconhecimento da inconstitucionalidade da lei tributária aparece o controle incidental (difuso e concreto). Como regra, a decisão proferida por intermédio desse instrumento de averiguação de constitucionalidade dos atos normativos só atinge as partes envolvidas na causa, ou seja, a eficácia da norma para o caso concreto. Todavia, no sistema brasileiro a resolução do Senado e a súmula vinculante foram ferramentas criadas para expandir os efeitos destes julgamentos. $\mathrm{O}$ primeiro tem o condão de fazer com que decisão passe a ser dotada de efeitos erga omnes, enquanto o segundo confere efeito vinculante à decisão. Paralelamente, o Supremo Tribunal Federal entende que a legislação nacional transformou o instituto da repercussão geral em verdadeira forma de atribuição de efeitos vinculantes ao julgamento proferido pelo STF em recursos extraordinários, determinando o destino dos demais processos, sobrestados e futuros, sobre o tema. Assim, tanto a resolução do Senado como a súmula vinculante e a repercussão geral são capazes de conferir o direito a terceiros contribuintes (estranhos à relação jurídica na qual foi reconhecida a inconstitucionalidade, mas que se subsomem à regra-matriz de incidência tributária) a terem de volta os valores pagos a título de tributo declarado inconstitucional.

Contudo, existe instrumento capaz de barrar o fenômeno de transformação de pagamentos devidos em pagamentos indevidos. Trata-se da modulação de efeitos das decisões do Supremo Tribunal Federal. Esse mecanismo foi criado para alterar o regular efeito ex tunc das decisões declaratórias de inconstitucionalidade (e não de constitucionalidade), tornando-o ex nunc ou pro futuro. Sua utilização na seara tributária é contestável, haja vista que inverte a lógica própria do direito (para cada ato ilícito existe uma sanção) e da Constituição brasileira (nulidade das leis inconstitucionais), além de atribuir direito fundamentais que só abrangem o cidadão (segurança jurídica e proteção da confiança legítima) ao Poder Público. Mesmo assim, o Supremo Tribunal Federal vem fazendo uso desse mecanismo. Por conseguinte, caso seja manejada, a modulação de efeitos inviabilizará eventuais pedidos de restituição de indébito, uma vez que os pagamentos passados restam intocados, ou seja, não haverá pagamento indevido.

O último tema afeito ao processo de reconhecimento da invalidade das leis consiste no controle de constitucionalidade pela Administração, o qual não foi resolvido pela doutrina, porém é pacificamente inadmitido pela jurisprudência dos tribunais administrativos e judiciais brasileiros, bem como pela legislação. Por essa razão, muito embora seja via legítima para a repetição ou compensação de tributo, o 
processo administrativo não poderá ser usado para declaração de inconstitucionalidade das exações.

Uma crítica importante que foi trazida nesse momento do estudo foi a de que não há de se falar em simples "não aplicação" da lei pelos tribunais administrativos, situação supostamente distinta do verdadeiro controle de constitucionalidade das leis, que ficaria a cargo tão somente do Poder Judiciário. Ora, dado o ilícito legislativo de produzir leis inconstitucionais, deve ser aplicada a respectiva sanção, vale dizer, a declaração de sua invalidade. A "não aplicação" da lei inconstitucional a um caso específico equivale ao controle de constitucionalidade incidental (concreto e difuso), que, embora não culmine em retirada da validade da lei, mas apenas no afastamento de sua eficácia entre as partes, é facultada somente ao Judiciário pela Constituição brasileira.

Pois bem. Munido de manifestação judicial reconhecendo a invalidade do ato normativo, bem como que os pagamentos efetuados no passado foram indevidos, completo está o antecedente da norma de restituição de tributos inconstitucionais, dando azo à relação jurídica posta no consequente da mesma norma.

No que toca o consequente normativo da restituição de tributo inconstitucional, a legitimidade ativa na ação de repetição de indébito é conferida ao sujeito passivo da obrigação tributária, vale dizer, àquele que efetuou o pagamento dos valores a título de tributo e que, agora, possui o direito subjetivo de se voltar contra o ente público para reaver tais montantes.

Porém, grande problemática surge em torno do artigo 166 do Código Tributário Nacional, cujos dizeres, em síntese, estabelecem que somente quem arcou com o ônus financeiro do tributo é que detém legitimidade para requerer a sua restituição. Disto construiu-se a separação entre "contribuinte de fato" e "contribuinte de direito", bem como entre "tributos diretos" e "tributos indiretos". Depois de analisada a jurisprudência e a doutrina sobre o tema, conclui-se que não é possível aceitar a regra posta no artigo 166 do CTN nos moldes traçados pelo Superior Tribunal de Justiça, $i$ ) em face da dificuldade de conceituar a repercussão dos tributos, além de se tratar de categoria do direito econômico/financeiro, de modo que a classificação dos tributos entre diretos e indiretos é impraticável; ii) porque a prova que o dispositivo pede que seja produzida pelo "contribuinte de direito" é impossível, e a autorização pelo "contribuinte de fato" tampouco factível, razão pela qual o dispositivo acaba por suprimir o direito à restituição de tributos; iii) já que o fisco só 
tem conhecimento do contribuinte legal, nunca do contribuinte de fato; e, assim, o eventual problema do equilíbrio econômico deve ser resolvido entre ambos por via de ação de regresso, de natureza privada.

Por conseguinte, a questão da legitimidade ativa da repetição de indébito tributário só pode ser resolvida de uma forma: será sempre do sujeito passivo da obrigação tributária, que, cumprindo seu dever, pagou tributo e, portanto, tem direito de reavê-lo, haja vista sua inconstitucionalidade. Desse modo, a figura do "contribuinte de fato" não pode, em nenhuma situação, funcionar como barreira ao direito de repetição de indébito do contribuinte legal e, muito menos, poderia lhe ser atribuído o direito de demandar quantias indevidamente pagas pela via repetitória.

Por essas razões, somente é possível uma adequada aplicação do artigo 166 para casos de substituição tributária, nos quais: i) o substituído será, via de regra, parte legítima para pleitear tributos inconstitucionais que foram arrecadados pelo Erário, haja vista que possui presunção a seu favor de ter arcado com o ônus da tributação; ii) houve pagamento de tributo inconstitucional pelo substituto, que poderá provar ter assumido o respectivo encargo para que seja legítimo seu direito à restituição do indébito; iii) se o substituto operava suas atividades repassando o encargo tributário ao substituído, este poderá conceder àquele a autorização prevista do artigo 166, garantindo a legitimidade ativa.

No que tange à responsabilidade tributária, a fenomenologia normativa é diversa, pois o responsável passa a ocupar o lugar do contribuinte na norma da obrigação tributária. Por conseguinte, ao efetuar o pagamento indevido, o responsável tributário é quem tem direito à repetição.

Em contraposição ao sujeito ativo da relação de restituição de indébito, há o sujeito passivo, ou seja, o devedor, obrigado a devolver os tributos indevidamente levados aos Cofres Públicos. Tendo em vista que a relação de restituição de tributos é o reverso da obrigação tributária, o sujeito passivo da repetição de indébito só pode ser o sujeito ativo da obrigação tributária (artigo 119, CTN), quer dizer, o Poder Público, que tem capacidade tributária ativa e recebeu tributos indevidos.

Ao final do Segundo Capítulo, discorreu-se sobre o último critério do consequente da norma padrão de restituição de tributos inconstitucionais, o quantum restituível, que, em síntese, equivale à entrega pelo Fisco ao contribuinte dos montantes inconstitucionalmente pagos, como se tributos perfeitamente válidos fossem. 
Dando continuidade à análise, no Capítulo Terceiro foram objeto de estudo os acréscimos à restituição que devem ser igualmente satisfeitos pelo Poder Público, de modo a trazer o contribuinte lesado ao status quo ante ao pagamento indevido, afinal, somente assim restam completamente ressarcidos os danos experimentados pelo pagamento de tributo inconstitucional.

Hodiernamente, não restam mais dúvidas sobre a necessidade de correção monetária do indébito, desde a data em que o pagamento foi feito ao Estado.

Ademais, a Fazenda Pública, ao restituir valores indevidamente pagos a título de tributo pelos contribuintes, deverá, além de restituir os juros indevidamente recolhidos aos Cofres Públicos (artigo 167, caput do CTN), fazê-lo mediante a aplicação de juros compensatórios, desde o pagamento indevido (artigo 167, parágrafo único do $\mathrm{CTN}$ ), sendo controversa a incidência de juros de mora (de 1\% ao mês) a partir do trânsito em julgado da decisão determinando a obrigação estatal. A dúvida se instala à medida que, apesar da taxa de juros Selic ter aparentemente englobado todo e qualquer fator de correção do indébito tributário, as diferentes espécies de juros têm objetivos e pressupostos diversos: enquanto os juros compensatórios são cobrados a título de rendimento do capital; os juros moratórios têm como escopo indenizar o indivíduo pelos danos sofridos em decorrência da expropriação de seus bens, com incidência a partir da exigibilidade da dívida, ou seja, a partir do trânsito em julgado da decisão condenando a Fazenda Pública.

Por fim, como último acréscimo a ser indenizado pelo Estado, aparecem as penalidades pecuniárias (ou multas), de qualquer natureza, que foram pagas conjuntamente com a obrigação principal tributária, posteriormente declarada inconstitucional. Porém, advertiu-se que as infrações de caráter formal não prejudicadas pela inconstitucionalidade subsistirão, não devendo ser devolvidas ao contribuinte.

De toda sorte, e apesar da oscilação das decisões proferidas pelo Superior Tribunal de Justiça, não há dúvida de que toda a disciplina trazida sobre correção monetária, juros e multas no CTN e na legislação fiscal ordinária é plenamente aplicável à restituição de tributos inconstitucionais, por força de sua natureza tributária.

Passou-se, assim, ao Capítulo Quarto, no qual se expõe que as vias postas à disposição do contribuinte para a efetivação da restituição de tributos indevidamente pagos são o processo administrativo e o judicial. Por quaisquer dos dois caminhos o 
sujeito passivo da obrigação tributária poderá requerer a compensação ou repetição dos montantes inconstitucionalmente recolhidos ao Erário, tendo sempre o ônus de provar o recolhimento das quantias indevidas.

Depois de examinado tanto o nascimento como o direito processual da relação de restituição de tributos, foi possível, já no Capítulo Quinto da presente exposição, passar ao estudo das cinco formas de extinção da relação de indébito tributário: decadência, prescrição, compensação, restituição administrativa e pagamento por precatórios.

A decadência do direito do contribuinte é configurada pela perda de sua legitimidade para repetir o indébito na esfera administrativa, em razão de decurso do período de tempo previsto em lei (cinco anos) como máximo para ser exercitado tal direito. Por sua vez, a prescrição, que também advém depois do período de cinco anos, fulmina direito de o contribuinte reaver pela via judicial tributos indevidamente pagos. Ambas são regidas pelas normas jurídicas dedicadas à matéria tributária, o que significa a aplicação do artigo 168 e 169 do CTN para a contagem do prazo decadencial e prescricional dos pedidos e ações de repetição de indébito. Afinal, muito embora se esteja diante de situação de inconstitucionalidade, não há de se cogitar de imprescritibilidade das ações de repetição de indébito. O que é imprescritível é o direito de arguir objetivamente a harmonia de certo ato normativo com a Constituição. Já os direitos subjetivos decorrentes dessa incompatibilidade perante o texto constitucional, como o da restituição de tributos inválidos, são sim prescritíveis, devendo ser levantados dentro do lapso temporal previsto pelo sistema jurídico para que possam ser efetivados.

O termo a quo a ser utilizado para a contagem do prazo prescricional é motivo para constante disputa doutrinária. A seu turno, na jurisprudência do STJ, inicialmente admitia-se que a decisão que declara a inconstitucionalidade da lei tributária seria o instante inicial do prazo de cinco anos, de modo que ela teria o condão de reabrir os prazos prescricionais para que o contribuinte requeresse montantes indevidamente pagos. A partir de 2003, esse posicionamento foi revisto, passando a entender-se que o próprio pagamento do tributo configura o termo a quo para a contagem do prazo.

Muito embora sejam fortes os argumentos dos defensores da tese de que a decisão do STF, a resolução do Senado ou a súmula vinculante sejam os marcos iniciais do prazo para a restituição de tributos inconstitucionais - uma vez que é a 
declaração de inconstitucionalidade que transforma o pagamento devido em pagamento indevido, gerando a actio nata -, concluiu-se, pela leitura sistemática dos artigos 165 e 168 do Código Tributário Nacional, bem como pela análise do seu Anteprojeto, ser de fato o pagamento indevido o elemento a ser levado em consideração para a contagem do prazo prescricional. Isto porque a tese em sentido contrário só teria sentido se se entendesse que é o inciso II do artigo 168, cujo conteúdo determina ser a partir da decisão judicial que tenha reformado, anulado, revogado ou rescindido a decisão condenatória a contagem do prazo prescricional, que deve ser aplicado por analogia à restituição de tributos inconstitucionais. Entretanto, é o inciso I do artigo 168, determinando ser a partir da extinção do crédito tributário (pagamento) o início do prazo prescricional, que regula o prazo para a restituição de tributos inconstitucionais. Este deve ser o dispositivo guia da matéria, haja vista que, em seu texto, é feita referência expressa aos pagamentos indevidos na forma do artigo 165, inciso I do CTN, exatamente onde se enquadra a figura do pagamento de tributos inconstitucionais.

Assim, são os últimos cinco anos, terminando na data da publicação da parte dispositiva do acórdão do STF reconhecendo a inconstitucionalidade da lei tributária no Diário Oficial que serão passíveis de repetição, pois somente os pagamentos indevidos compreendidos dentro deste lapso temporal é que não terão sido consumidos pela decadência/prescrição. No caso do controle de constitucionalidade incidental é a data de publicação da resolução do Senado ou súmula vinculante que será levada em conta. Finalmente, para a sentença/acórdão proferido no processo individual promovido pelo contribuinte, deve-se atentar para o fato de que a propositura da ação interrompe a prescrição, de modo que os valores recolhidos indevidamente nos últimos 5 (cinco) anos anteriores ao início do litígio judicial deverão ser restituídos.

Foi essa a opção feita pelo legislador nacional, ao deixar a restituição de tributos inconstitucionais dentro da mesma disciplina que as demais espécies de restituição de tributos.

Sobre a terceira forma de extinção da relação de indébito do Fisco, tem-se que as regras do CTN e da legislação federal sobre compensação são plenamente aplicáveis à hipótese de declaração de inconstitucionalidade da lei tributária. Destarte, tanto a autocompensação como a compensação baseada em sentença transitada em julgado em favor do contribuinte poderão ensejar o encontro de contas, promovendo a 
extinção da relação de débito do Fisco conjuntamente com relação em que o contribuinte é devedor do Estado, no que forem equivalentes.

Inclusive, o artigo 74, § 12, II, “f”, da Lei $\mathrm{n}^{\circ}$ 9.430/96 estabeleceu as hipóteses em que a inconstitucionalidade do ato normativo será argumento legítimo para compensações tributárias, atendo-se fielmente aos modelos e efeitos do controle de constitucionalidade vigentes na ordem jurídica brasileira. Destarte, cabe à Administração Pública se curvar à decisão do Supremo, autorizando restituições e compensações de tributos que haviam sido recolhidos com base na lei inconstitucional.

A restituição administrativa, quarta espécie de extinção da relação de indébito do fisco, é forma prevista em lei federal e tradicionalmente aceita pelo direito tributário como forma de pagamento dos montantes à conta do credor e consequente extinção da obrigação da Fazenda Pública.

Como quinta forma extintiva da relação de restituição de tributos inconstitucionais, aparece o pagamento por precatórios, disciplinado pelo artigo 100 da Constituição, sendo essa a clássica forma de adimplemento das obrigações do Poder Público, pela qual a requisição de pagamentos, que serão realizados por ordem cronológica, culminará no fim da relação de indébito tributário.

Alcança-se, então, o sexto e último capítulo do trabalho ora apresentado. A importância dos apontamentos trazidos nessa oportunidade é clara, à medida que é possível que os contribuintes e a Fazenda Pública se deparem com situação em que haja conflito entre a sentença transitada em julgado entre as partes, sobre a qual se cristalizou a coisa julgada, e julgamento do Supremo Tribunal Federal em controle de constitucionalidade principal, ou em controle de constitucionalidade incidental com subsequente resolução do Senado, súmula vinculante ou ainda proferida em recurso extraordinário dotado de repercussão geral. Vem a lume, assim, a coisa julgada inconstitucional, com reflexos diretos na relação de restituição de tributos inválidos.

Muito embora discussões jurisprudenciais acerca da força da coisa julgada em matéria tributária tenham gerado insegurança sobre o tema, é certo que não pode, de forma alguma, ser mitigada a importância da coisa julgada nesta seara. Todavia, como ocorre em outros ramos do direito, certas situações podem dar ensejo à revisão da coisa julgada, como a declaração de inconstitucionalidade proferida pelo Supremo Tribunal Federal por exemplo. 
O manejo da ação rescisória convém para tanto, com fundamento no artigo 485, inciso V, do Código de Processo Civil, devendo ser afastada a aplicação da Súmula 343 do STF. Nesse sentido, os contribuintes poderão fazer uso de ação rescisória diante de decisão do STF que vá de encontro com coisa julgada contra si, desde que os efeitos do julgamento lhes abarquem. O contribuinte, no pedido da ação rescisória, poderá requerer não só o fim da obrigação de recolher o tributo em questão aos cofres públicos, como também a restituição dos valores indevidamente pagos nos últimos cinco anos. 


\section{REFERÊNCIAS BIBLIOGRÁFICAS}

Allage, Gonçalo Bonnet. Prazo prescricional nas ações de restituição de indébito tributário fundadas em declaração de inconstitucionalidade proferida pelo STF. Revista de Estudos Tributários - v. 6 n. 31 maio-jun. 2003, p. 7-13.

Amaro, Luciano. Direito Tributário Brasileiro. 16. ed. São Paulo: Saraiva, 1997.

AMORIm Filho, Agnelo. Critério científico para distinguir prescrição de decadência e para identificar as ações imprescritíveis. In: Revistas dos Tribunais 744 outubro/1997- Memória do Direito Brasileiro, 86 ano, p. 725 - 750.

ANDRADE FILHO, Edmar Oliveira. Repetição de indébito tributário: um enfoque constitucional. In: Rocha, Valdir de Oliveira (Coord.). Problemas de processo judicial tributário: $3^{\circ}$ volume. São Paulo: Dialética, 1999.

Andrade, Fábio Martins de. Modulação em Matéria Tributária - o argumento pragmático ou consequencialista de cunho econômico e as decisões do STF. São Paulo: Quartier Latin, 2011.

ANDRADE, José Maria de Arruda. Interpretação da Norma Tributária, São Paulo: MP ed, 2006.

ANDREOLI, Giuseppe. Ripetizioni dell'indebito. Podova: Cedam, 1940.

AraúJo, JosÉ Henrique Mouta. Impugnação e Embargos do Devedor nos Título Executivos Inconstitucionais: a Ampliação do Caráter Vinculante das Decisões do STF, Revista Dialética de Direito Processual, n. 71, p. 50 - 61.

Araúso, Wanessa Mendes de. A declaração de inconstitucionalidade e suas implicações na repetição de indébito tributário. Revista de Direito Tributário da APET - v. 7 n. 26 jun. 2010. São Paulo: APET, 2010, p. 89-106.

Assis, Araken de. Manual da Execução. 13. ed. São Paulo: Editora Revista dos Tribunais, 2010.

- Eficácia da Coisa Julgada Inconstitucional. Revista Dialética de Direito Processual no 4, p. $9-26$.

AtAliBA, Geraldo. Hipótese de Incidência Tributária. São Paulo: Malheiros, 2010, $6^{\text {a }}$ ed.

Ávila, Humberto. Segurança Jurídica - Entre permanência, mudança e realização no Direito Tributário. São Paulo: Malheiros, 2011.

Baleerro, Aliomar. Direito Tributário Brasileiro. 11. ed. Rio de Janeiro: Editora Forense, 2006.

BArbosa, Rui. Atos inconstitucionais. 3. ed. Campinas: Russell Editores, 2010. 
Bottallo, Eduardo Domingos. Processo Administrativo Tributário e Processo Judicial Tributário. In: Barreto, Aires F.; Bottallo, Eduardo Domingos. (Org.). Curso de Iniciação em Direito Tributário. São Paulo: Dialética: Dialética, 2004, p. 239-263.

- Repetição do Indébito Tributário e o Art. 166 do Código Tributário Nacional. Revista da Faculdade de Direito USP. São Paulo, v. 94, 1999.

BARReto, Aires Fernandino. Base de cálculo, alíquota e princípios constitucionais. 2. ed. São Paulo: Max Limonad, 1998.

BArreto, Paulo Ayres. Contribuições: regime jurídico, destinação e controle. São Paulo: Noeses, 2006.

- Segurança jurídica no planejamento tributário. In: RocHA, Valdir de Oliveira (Coord.). Grandes questões atuais do direito tributário, 14, São Paulo: Dialética, 2010, p. 268-282.

. Imposto sobre a renda e preços de transferência. São Paulo: Dialética, 2001.

Barroso, Luis Roberto. O controle de Constitucionalidade no Direito Brasileiro. 4. ed. São Paulo, Saraiva. 2012.

Becker, Alfredo Augusto. Teoria Geral do Direito Tributário. 4. ed. São Paulo: Marcial Pons, 2007.

Berno, Cheryl. Restituição de Tributo Inconstitucional. Curitiba: Juruá Editora, 2009.

Bichara, Luiz Gustavo A. S. A possibilidade de o Supremo Tribunal Federal atribuir efeitos ex nunc ou pro futuro à decisão que considera inconstitucional lei tributária, in: CeZAROTI, Guilherme (Coord.). Repetição de Indébito Tributário. São Paulo: Quartier Latin, 2005, p. 57-86.

BitTar, Djalma. Processo Tributário. In: Santi, Eurico Marcos Diniz de (Coord.). Curso de Especialização em Direito Tributário- Homenagem ao Professor Paulo de Barros Carvalho, Rio de Janeiro: Forense, 2006, p. 579 - 600.

Bittencourt, Lúcio. O Contrôle Jurisdicional da Constitucionalidade das Leis. Rio de Janeiro: Editora Forense, 1948.

BobBio, Norberto. Teoria da Norma Jurídica. 3. ed. São Paulo: Edipro, 2005.

Borges, José Souto Maior. Lançamento tributário. 2. ed. São Paulo: Malheiros, 1999.

Botallo, Eduardo Domingos. Repetição do Indébito Tributário e o Art. 166 do Código Tributário Nacional. Revista da Faculdade de Direito USP. São Paulo, v. 94,1999 , p. $251-262$.

2009.

. Curso de Processo Administrativo Tributário. 2. ed. São Paulo: Malheiros, 
Brasil. Ministério da Fazenda. Acórdão 03.239 do Processo 10930.002479/97-31. Relator: Conselheiro Wilfrido Augusto Marques. Julgamento: 19 mar. 2001. Órgão Julgador: Câmara Superior de Recursos Fiscais, $1^{\text {a }}$ Turma. Publicação: DOU, 01 out. 2001.

. Ministério da Fazenda. Acórdão 102-46584 do Processo 13116.000236/9902. Relator: Conselheiro Leonardo Henrique Magalhães de Oliveira. Julgamento: 02 jan. 2004. Órgão Julgador: $1^{\mathrm{o}}$ Conselho de Contribuintes/MF, $2^{\mathrm{a}}$ Câmara. Publicação: 02 dez. 2004.

. Ministério da Fazenda. Acórdão 201.78172 do Processo 10882.000780/2002-33. Relator: Conselheiro Sérgio Gomes Velloso. Julgamento: 26 jan. 2005. Órgão Julgador: $2^{\circ}$ Conselho de Contribuintes, $1^{\mathrm{a}}$ Câmara. Publicação: 26 jan. 2005.

Ministério da Fazenda. Acórdão 204-00.054 do Processo 10120.005031/2001-33. Julgamento: 13 abr. 2005. Órgão Julgador: $2^{\circ}$ Conselho de Contribuintes, $4^{\mathrm{a}}$. Câmara. Publicação: 13 abr. 2005.

Ministério da Fazenda. Acórdão 204-01422 do Processo 13710.002436/2001-68. Relator: Conselheiro Julio Cesar Alves Ramos. Julgamento: 28 jun. 2006. Órgão Julgador: $2^{\circ}$ Conselho de Contribuinte/MF, $4^{\mathrm{a}}$ Câmara. Publicação: 28 jun. 2006.

Ministério da Fazenda. Acórdão 303.31188 do Processo 10660.003434/2001-31. Julgamento: 18 fev. 2004. Órgão Julgador: $3^{\circ}$ Conselho de Contribuintes, $3^{\text {a }}$ Câmara. Publicação: DOU, 22 out. 2004).

. Ministério da Fazenda. Acórdão CSRF/01-05.308. Relator: José Clóvis Alves. Julgamento: 21 set. 2005. Órgão Julgador: Câmara Superior de Recursos Fiscais, Primeira Turma. Publicação: 21 set. 2005.

- Ministério da Fazenda. Acórdão $n^{o}$ 101-96.895 do Processo 11618.004894/2005-98. Relator: Antonio José Praga de Souza. Julgamento: 15 ago. 2008. Órgão Julgador: $1^{\mathrm{o}}$ Conselho de Contribuintes. $1^{\mathrm{a}}$ Câmara. $3^{\mathrm{a}}$ Turma. Publicação: 15 ago. 2008.

. Ministério da Fazenda. Secretaria da Receita Federal. Acórdão 16-15663 de 04 de dezembro de 2007. Ementa: $\mathrm{AI} n^{0}$ 37.088.854-5 de 15 ago. 2007. Publicação: DOU, 04 dez. 2007.

Senado Federal. Resolução n. 11/95. Suspende a execução do art. $8^{\circ}$ da Lei $\overline{\mathrm{n}^{0}}$ 7.689, de 15 de dezembro de 1988. Brasília, 04 abr. 1995.

Senado Federal. Resolução $n^{\circ}$ 14. Suspende a execução da expressão "avulsos, autônomos e administradores," contida no inciso I do art. $3^{\circ}$ da Lei $n^{\circ} 7.787$, de 1989. Brasília: DOU, 19 abr. 1995.

Senado Federal. Resolução $n^{\circ} 50$. Suspende a execução de dispositivos do Decreto-Lei n 2.288, de 23 de julho de 1986. Brasília: DOU, 10 out. 1995. 
. Senado Federal. Resolução $n^{\circ} 73$. Suspende a execução do caput do art. 10 da Lei $\mathrm{n}^{\circ} 2.145$, de 29 de dezembro de 1953 , com a redação dada pelo art. $1^{\circ}$ da Lei $\mathrm{n}^{\circ}$ 7.690, de 15 de dezembro de 1988. Brasília: DOU, 15 dez. 1995.

Superior Tribunal de Justiça. Agravo em Recurso Especial 199.089-PE. Relator: Ministro Arnaldo Esteves Lima. Julgamento: 05 fev. 2013. Órgão Julgador: Primeira Turma. Publicação: DJe, 20 fev. 2013.

Superior Tribunal de Justiça. Agravo Regimental no Agravo de Instrumento

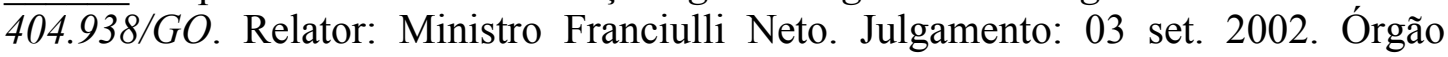
Julgador: Segunda Turma. Publicação: 07 abr. 2003.

Superior Tribunal de Justiça. Agravo Regimental no Agravo de Instrumento 452.588/SP. Relator: Ministro Francisco Falcão. Julgamento: 10 fev. 2004. Órgão Julgador: Primeira Turma. Publicação: DJ, 5 abr. 2004.

Superior Tribunal de Justiça. Agravo Regimental no Agravo de Instrumento 514.977/SP. Relator: Ministro João Otávio de Noronha. Julgamento: 19 fev. 2004. Órgão Julgador: Segunda Turma. Publicação: DJ, 22 mar. 2004.

Superior Tribunal de Justiça. Agravo Regimental no Agravo de Instrumento 629.184/MG. Relator: Ministro José Delgado. Julgamento: 03 maio 2005. Órgão Julgador: Primeira Turma. Publicação: DJ, 13 jun. 2005.

Superior Tribunal de Justiça. Agravo Regimental no Agravo de Instrumento 626.191/SP. Relator: Ministro Humberto Martins. Julgamento: 15 out. 2009. Órgão Julgador: Segunda Turma. Publicação: DJe, 23 out. 2009.

Superior Tribunal de Justiça. Agravo Regimental no Agravo de Instrumento 750.438/MG. Relator: Ministro Herman Benjamin. Julgamento: 10 abr. 2004. Órgão Julgador: Segunda Turma. Publicação: DJe, 30 set. 2008.

Superior Tribunal de Justiça. Agravo Regimental no Recurso Especial 267.718/DF. Relatora: Ministra Laurita Vaz. Julgamento: 07 mar. 2002. Órgão Julgador: Segunda Turma. Publicação: DJ, 05 maio 2003.

Superior Tribunal de Justiça. Agravo Regimental no Recurso Especial 429.413/RJ. Relator: Ministro Franciulli Netto. Julgamento: 19 set. 2003. Órgão Julgador: Segunda Turma. Publicação: DJ, 13 out. 2003.

Superior Tribunal de Justiça. Agravo Regimental no Recurso Especial 469.863/SP. Relator Ministro Luis Fux. Julgamento: 05 jun. 2003. Órgão Julgador: Primeira Turma. Publicação: DJ, 04 ago. 2003.

Superior Tribunal de Justiça. Agravo Regimental no Recurso Especial 597.505/RS. Relator: Ministro Teori Albino Zavascki. Julgamento: 03 fev. 2004. Órgão Julgador: Primeira Turma. Publicação: DJ, 25 fev. 2004.

Superior Tribunal de Justiça. Agravo Regimental no Recurso Especial 621.556/SP. Relator: Ministro Luiz Fux. Julgamento: 12 abr. 2005. Órgão Julgador: Primeira Turma. Publicação: DJ, 02 maio 2005. 
- Superior Tribunal de Justiça. Agravo Regimental no Recurso Especial 734.647/SP. Relator: Ministro Franciulli Netto. Julgamento: 13 set. 2005. Órgão Julgador: Segunda Turma. Publicação: DJ, 10 nov. 2006.

. Superior Tribunal de Justiça. Agravo Regimental no Recurso Especial 740.992/RS. Relator: Ministro Franciulli Netto. Julgamento: 18 ago. 2005. Órgão Julgador: Segunda Turma. Publicação: DJ, 13 fev. 2006.

Superior Tribunal de Justiça. Agravo Regimental no Recurso Especial 745.267/RS. Relator: Ministro Franciulli Netto. Julgamento: 18 ago. 2005. Órgão Julgador: Segunda Turma. Publicação: DJ, 05 set. 2006.

Superior Tribunal de Justiça. Agravo Regimental no Recurso Especial 850.437/PR. Relator: Ministro Humberto Martins. Julgamento: 08 dez. 2008. Órgão Julgador: Segunda Turma. Publicação: Dje 03 fev. 2009.

Superior Tribunal de Justiça. Agravo Regimental no Recurso Especial 1.081.076/SP. Relator: Ministro Benedito Gonçalves. Julgamento: 17 jun. 2010. Órgão Julgador: Primeira Turma. Publicação: DJe, 01 jul. 2010.

Superior Tribunal de Justiça. Agravo Regimental no Recurso Especial 1.135.966/PR. Relator: Ministro Humberto Martins. Julgamento: 17 nov. 2009. Órgão Julgador: Segunda Turma. Publicação: DJe, 25 nov. 2009.

- Superior Tribunal de Justiça. Agravo Regimental nos Embargos de Divergência no Recurso Especial 808.747/RS. Relator: Ministro Castro Meira. Julgamento: 25 out. 2006. Órgão Julgador: Primeira Seção. Publicação: DJ, 13 nov. 2006.

- Superior Tribunal de Justiça. Embargos de Declaração no Agravo Regimental no Agravo de Instrumento 626.046/RS. Relator: Ministro Luiz Fux. Julgamento: 02 ago. 2005. Órgão Julgador: Primeira Turma. Publicação: DJ, 29 ago. 2005.

- Superior Tribunal de Justiça. Embargos de Declaração no Agravo Regimental nos Embargos de Declaração no Recurso Especial 871.152/SP. Relator: Ministro Luiz Fux. Julgamento: 3 ago. 2010. Órgão Julgador: Primeira Turma. Publicação: DJe, 19 ago. 2010.

- Superior Tribunal de Justiça. Embargos de Declaração no Agravo Regimental nos Embargos de Divergência no Recurso Especial 263.433/CE. Relator: Ministra Eliana Calmon. Julgamento: 27 ago. 2003. Órgão Julgador: Primeira Seção. Publicação: DJ, 29 set. 2003.

. Superior Tribunal de Justiça. Embargos de Divergência no Recurso Especial 189.052/SP. Relator Ministro Paulo Medina. Julgamento: 12 mar. 2003. Órgão Julgador: Primeira Seção. Publicação: DJ, 03 nov. 2003.

. Superior Tribunal de Justiça. Embargos de Declaração no Recurso Especial 396.077/SC. Relator: Ministro Castro Meira. Julgamento: 09 jun. 2004. Órgão Julgador: Primeira Seção. Publicação: DJ, 09 ago. 2004. 
. Superior Tribunal de Justiça. Embargos de Divergência no Recurso Especial 417.459/SP. Relator: Ministro Franciulli Netto. Julgamento: 08 jun. 2004. Órgão Julgador: Primeira Seção. Publicação: DJ, 11 out. 2004, p. 219.

. Superior Tribunal de Justiça. Embargos de Divergência no Recurso Especial. 488.992/MG. Relator: Ministro Teori Albino Zavascki. Julgamento: 26 maio 2004. Órgão Julgador: Primeira Seção. Publicação: DJ, 07 jun. 2004.

. Superior Tribunal de Justiça. Embargos de Declaração no Recurso Especial 635.856/SC. Relator: Ministro Herman Benjamin. Julgamento: 12 jun. 2007. Órgão Julgador: Segunda Turma. Publicação: DJ, 19 dez. 2007;

Superior Tribunal de Justiça. Embargos de Divergência no Recurso Especial 669.139/SE. Relator: Ministro Humberto Martins. Julgamento: 23 maio 2007. Órgão Julgador: Primeira Seção. Publicação: DJ, 04 jun. 2007;

. Superior Tribunal de Justiça. Embargos de Declaração no Recurso Especial 811.282/MG. Relator: Ministro Castro Meira. Julgamento: 03 out. 2006. Órgão Julgador: Segunda Turma. Publicação: DJ, 11 out. 2006;

. Superior Tribunal de Justiça. Embargos de Divergência no Recurso Especial 1.018.533/SP. Relator: Ministra Eliana Calmon. Julgamento: 10 dez. 2008. Órgão Julgador: Primeira Seção. Publicação: DJe, 02 set. 2009.

Superior Tribunal de Justiça. Embargos de Divergência no Recurso Especial 1.137.738/SP. Relator: Ministro Luiz Fux. Julgamento: 09 dez. 2009. Órgão Julgador: Primeira Seção. Publicação: DJe, 01 fev. 2010.

. Superior Tribunal de Justiça. Embargos de Divergência no Recurso Especial 651.224/SP. Relatora: Ministra Eliana Calmon. Julgamento: 10 maio 2006. Órgão Julgador: Primeira Seção. Publicação: DJ, 19 jun. 2006.

. Superior Tribunal de Justiça. Embargos de Divergência no Recurso Especial 195.711/RS. Relator: Ministro João Otávio de Noronha. Julgamento: 27 ago. 2003. Órgão Julgador: Primeira Seção. Julgamento: DJ, 22 set. 2003.

. Superior Tribunal de Justiça. Embargos de Divergência no Recurso Especial 162.914/PR. Relator: Ministro Humberto Gomes de Barros. Julgamento: 19 out. 1999. Órgão Julgador: Primeira Seção. Publicação: DJ, 04 set. 2000.

. Superior Tribunal de Justiça. Embargos de Divergência no Recurso Especial 423.994/MG. Relator: Ministro Francisco Peçanha Martins. Julgamento: 08 out. 2003. Órgão Julgador: Primeira Seção. Publicação: DJ, 05 abr. 2004.

. Superior Tribunal de Justiça. Embargos de Divergência no Recurso Especial 42.720-5/RS. Relator: Ministro Humberto Gomes de Barros. Julgamento: 09 maio 1995. Órgão Julgador: Primeira Seção. Publicação: 05 jun. 1995.

. Superior Tribunal de Justiça. Embargos de Divergência no Recurso Especial 43.502/RS. Relator: Ministro Cesar Asfor Rocha. Julgamento: 25 abr. 1995. Órgão Julgador: Primeira Seção. Publicação: DJ, 29 maio 1995. 
. Superior Tribunal de Justiça. Embargos de Divergência no Recurso Especial 435.835/SC. Relator: Ministro Francisco Peçanha Martins. Relator para Acórdão: Ministro José Delgado. Julgamento: 2 mar. 2004. Órgão Julgador: Primeira Seção. Publicação: DJ, 04 jun. 2007.

. Superior Tribunal de Justiça. Embargos de Divergência no Recurso Especial 502.618/RS. Relator: Ministro João Otávio de Noronha. Julgamento: 08 jun. 2005. Órgão Julgador: Primeira Seção. Publicação: DJ, 01 jul. 2005.

. Superior Tribunal de Justiça. Embargos de Divergência no Recurso Especial 609.266/RS. Relator: Ministro Teori Albino Zavascki. Julgamento: 23 ago. 2006. Órgão Julgador: Primeira Seção. Publicação: DJ, 11 set. 2006.

. Superior Tribunal de Justiça. Embargos de Divergência no Recurso Especial 243463/SP. Relator: Ministro José Delgado. Relator do Acórdão: Ministro Francisco Falcão. Julgamento: 13 dez. 2004. Órgão Julgador: Primeira Seção. Publicação: DJ, 01 jul. 2005.

. Superior Tribunal de Justiça. Embargos de Divergência no Recurso Especial 548.343/PE. Relator: Ministro Luiz Fux. Julgamento: 08 fev. 2006. Órgão Julgador: Primeira Seção. Publicação: DJ, 20 fev. 2006.

Superior Tribunal de Justiça. Embargos de Divergência no Recurso Especial 181.479/SC. Relator: Ministro Franciulli Netto. Julgamento: 25 jun. 2003. Órgão Julgador: Primeira Seção. Publicação: DJ, 25 ago. 2003.

. Superior Tribunal de Justiça. Recurso Especial 95.262/MG. Relator: Ministro Ari Parglender. Julgamento: 14 abr. 1998. Órgão Julgador: Segunda Turma. Publicação: DJ, 04 maio 1998.

. Supremo Tribunal de Justiça. Recurso Especial 524.143/MG. Relator: Ministro Luiz Fux. Julgamento: 26 ago. 2003. Órgão Julgador: Primeira Turma. Publicação: DJ, 15 set. 2003.

. Superior Tribunal de Justiça. Recurso Especial 553.887/RJ. Relator: Ministro Castro Meira. Julgamento: 09 mar. 2004. Órgão Julgador: Segunda Turma. Publicação: 28 jun. 2004.

Superior Tribunal de Justiça. Recurso Especial 617.536/MG. Relator: Ministro Franciulli Netto. Julgamento: 07 out. 2004. Órgão Julgador: Segunda Turma. Publicação: DJ, 14 mar. 2005.

Superior Tribunal de Justiça. Recurso Especial 1.019.741/SP. Relator Ministro Mauro Campbell Marques. Julgamento: 16 dez. 2010. Órgão Julgador: Segunda Turma. Publicação: DJe, 08 fev. 2011.

Superior Tribunal de Justiça. Recurso Especial 1.086.051/SP. Relator: Ministro Castro Meira. Julgamento: 18 maio 2010. Órgão Julgador: Segunda Turma. Publicação: DJe, 02 jun. 2010. 
. Superior Tribunal de Justiça. Recurso Especial 1.111.189/SP. Relator: Ministro Teori Albino Zavascki. Julgamento: 13 maio 2009. Órgão Julgador: Primeira Seção. Publicação: DJe, 25 maio 2009.

Superior Tribunal de Justiça. Recurso Especial 1.114.404/MG. Relator: Ministro Mauro Campbell Marques. Julgamento: 10 fev. 2010. Órgão Julgador: Primeira Seção. Publicação: 01 mar. 2010.

Superior Tribunal de Justiça. Recurso Especial 1.120.244/SP. Relator: Ministro Muro Campbell Marques. Órgão Julgador: Segunda Turma. Publicação: DJe, 09 ago. 2011.

. Superior Tribunal de Justiça. Recurso Especial 1.147.362/MT. Relator: Ministro Castro Meira. Julgamento: 10 ago. 2010. Órgão Julgador: Segunda Turma. Publicação: DJe, 19 ago. 2010.

. Superior Tribunal de Justiça. Recurso Especial 1.150.518. Relator: Ministro Humberto Martins. Julgamento: 06 maio 2010. Órgão Julgador: Segunda Turma. Publicação: DJe, 17 maio 2010.

. Superior Tribunal de Justiça. Recurso Especial 1.299.303. Relatora: Ministra Diva Malerbi. Julgamento: 12 dez. 2012. Órgão Julgador: Primeira Seção. Publicação: DJe, 01 fev. 2013.

. Superior Tribunal de Justiça. Recurso Especial 129.627/PR. Relator: Ministro Francisco Peçanha Martins. Julgamento: 02 set. 1999. Órgão Julgador: Segunda Turma. Publicação: DJU, 25 out. 1999.

. Superior Tribunal de Justiça. Recurso Especial 143.716/DF. Relator: Ministro Hélio Mosimann. Julgamento: 01 dez. 1997. Órgão Julgador: Segunda Turma. Publicação: DJ, 25 fev. 1998.

. Superior Tribunal de Justiça. Recurso Especial 203.144/SP. Relator: Ministro Francisco Peçanha Martins. Julgamento: 16 ago. 2001. Órgão Julgador: Segunda Turma. Publicação: DJ, 05 nov. 2001.

. Superior Tribunal de Justiça. Recurso Especial 255.137/SC. Relator: Ministro Franciulli Netto. Julgamento: 10 dez. 2002. Órgão Julgador: Segunda Turma. Publicação: DJ, 31 maio 2004.

. Superior Tribunal de Justiça. Recurso Especial 255.213/SP. Relator: Ministro João Otávio de Noronha. Julgamento: 16 mar. 2006. Órgão Julgador: Segunda Turma. Publicação: DJ, 01 fev. 2006, p. 282.

. Superior Tribunal de Justiça. Recurso Especial 262.347/PR. Relator: Ministro Francisco Peçanha Martins. Julgamento: 16 abr. 2001. Órgão Julgador: Segunda Turma. Publicação: DJ, 24 set. 2001.

. Superior Tribunal de Justiça. Recurso Especial 284.084/SP. Relator: Ministro José Delgado. Julgamento: 05 fev. 2002. Órgão Julgador: Primeira Turma. Publicação: DJ, 25 mar. 2002. 
. Superior Tribunal de Justiça. Recurso Especial 332.494/SP. Relator: Ministro Franciulli Netto. Julgamento: 19 dez. 2003. Órgão Julgador: Segunda Turma. Publicação: DJ, 17 maio 2004.

. Superior Tribunal de Justiça. Recurso Especial 457.155/SE. Relator: Ministro Castro Meira. Julgamento: 4 nov. 2004. Órgão Julgador: Segunda Turma. Publicação: DJ, 7 mar. 2005.

. Superior Tribunal de Justiça. Recurso Especial 472.162/SP. Relator: Ministro João Otávio de Noronha. Julgamento: 9 dez. 2003. Órgão Julgador: Segunda Turma. Publicação: DJ, 9 fev. 2004.

. Superior Tribunal de Justiça. Recurso Especial 486.102/RS. Relator: Ministro Luiz Fux. Relator para o Acórdão: Ministro José Delgado. Julgamento: 16 dez. 2003. Órgão Julgador: Primeira Turma. Publicação: DJ, 30set. 2004.

Superior Tribunal de Justiça. Recurso Especial 509.897/DF. Relatora: Ministra Denise Arruda. Julgamento: 14 fev. 2006. Órgão Julgador: Primeira Turma. Publicação: DJ, 13 mar. 2006.

. Superior Tribunal de Justiça. Recurso Especial 526.655/SC. Relator: Luiz Fux. Julgamento: 17 fev. 2004. Órgão Julgador: Primeira Turma. Publicação: DJ, 14 mar. 2005.

- Superior Tribunal de Justiça. Recurso Especial 527.754/PR. Relatora: Ministra Denise Arruda. Julgamento: 04 abr. 2006. Órgão Julgador: Primeira Turma. Publicação: DJ, 24 abr. 2006.

- Superior Tribunal de Justiça. Recurso Especial 531.352/MG. Relator: Ministro Francisco Peçanha Martins. Julgamento: 06 dez. 2005. Órgão Julgador: Segunda Turma. Publicação: DJ, 13 fev. 2006;

. Superior Tribunal de Justiça. Recurso Especial 531.788. Relator: Ministra Eliana Calmon. Julgamento: 10 fev. 2004. Órgão Julgador: Segunda Turma. Publicação: DJ, 03 nov. 2003.

. Superior Tribunal de Justiça. Recurso Especial 544.638/DF. Relator: Ministro Luiz Fux. Julgamento: 26 nov. 2003. Órgão Julgador: Decisão Monocrática. Publicação: DJ, 03 dez. 2003.

. Superior Tribunal de Justiça. Recurso Especial 547.744/MG. Relator: Ministro Luiz Fux. Julgamento: 20 nov. 2003. Órgão Julgador: Primeira Turma. Publicação: DJ, 09 dez. 2003.

Superior Tribunal de Justiça. Recurso Especial 551.184/PR. Relator: Ministro Castro Meira. Julgamento: 21 out. 2003. Órgão Julgador: Segunda Turma. Publicação: 01 dez. 2003.

Superior Tribunal de Justiça. Recurso Especial 584.372/MG. Relator: Ministro Castro Meira. Julgamento: 17 mar. 2005. Órgão Julgador: Segunda Turma. Publicação: DJ, 23 maio 2005; 
. Superior Tribunal de Justiça. Recurso Especial 596.275/RJ. Relatora: Ministra Denise Arruda Julgamento: 19 set. 2006. Órgão Julgador: Primeira Turma. Publicação: DJ, 09 out. 2006.

. Superior Tribunal de Justiça. Recurso Especial 614.577/SC. Relator: Ministro Teori Albino Zavascki. Julgamento: 13 mar. 2004. Órgão Julgador: Primeira Turma. Publicação: DJ, 03 maio 2004.

- Superior Tribunal de Justiça. Recurso Especial 624.474/PB. Relator: Ministro Castro Meira. Julgamento: 15 mar. 2005. Órgão Julgador: Segunda Turma. Publicação: DJ, 23 maio 2005.

. Superior Tribunal de Justiça. Recurso Especial 639.092/BA. Relator Ministro Franciulli Netto. Julgamento 19 ago. 2004. Segunda Turma. Publicação: DJ, 01 fev. 2005.

. Superior Tribunal de Justiça. Recurso Especial 643.041/SP. Relator: Ministro João Otávio de Noronha. Julgamento: 24 ago. 2004. Órgão Julgador: Segunda Turma. Publicação: DJ, 11 out. 2004.

- Superior Tribunal de Justiça. Recurso Especial 643.989/PR. Relator: Ministro José Delgado. Julgamento: 18 set. 2004. Órgão Julgador: Primeira Turma. Publicação: DJ, 08 nov. 2004.

. Superior Tribunal de Justiça. Recurso Especial 644.411/RS. Relator: Ministro Castro Meira. Julgamento: 28 mar. 2006. Órgão Julgador: Segunda Turma. Publicação: DJ, 05 abr. 2006.

. Superior Tribunal de Justiça. Recurso Especial 648.423/SP. Relator: Ministro Francisco Peçanha Martins. Julgamento: 23 ago. 2005. Órgão Julgador: Segunda Turma. Publicação: DJ, 17 out. 2005.

. Superior Tribunal de Justiça. Recurso Especial 648.923/SP. Relator: Ministro Humberto Martins. Julgamento: 26 jun. 2007. Órgão Julgador: Segunda Turma. Publicação: DJ 03 ago. 2007.

. Superior Tribunal de Justiça. Recurso Especial 653.655/PR. Relator: Teori Albino Zavascki. Julgamento: 15 set. 2005. Órgão Julgador: Primeira Turma. Publicação: DJ, 26 set. 2005;

. Superior Tribunal de Justiça. Recurso Especial 676.051/AL. Relator: Ministro Teori Albino Zavascki. Julgamento: 15 mar. 2005. Órgão Julgador: Primeira Turma. Publicação: DJ, 04 abr. 2005.

. Superior Tribunal de Justiça. Recurso Especial 695.977/RS. Relator: Ministro José Delgado. Julgamento: 03 mar. 2005. Órgão Julgador: Primeira Turma. Publicação: DJ, 11 abr. 2005.

Superior Tribunal de Justiça. Recurso Especial 698.611/SP. Relatora: Ministra Eliana Calmon. Julgamento: 3 maio 2005. Órgão Julgador: Segunda Turma. Publicação: DJ, 6 jun. 2005. 
- Superior Tribunal de Justiça. Recurso Especial 698.876/SP. Relatora: Ministra Denise Arruda. Julgamento: 02 set. 2008. Órgão Julgador: Primeira Turma. Publicação: DJe, 22 set. 2008.

- Superior Tribunal de Justiça. Recurso Especial 737.388/RS. Relatora: Ministra Eliana Calmon. Julgamento: 04 set. 2007. Órgão Julgador: Segunda Turma. Publicação: DJ, 26 set. 2007.

Superior Tribunal de Justiça. Recurso Especial 741.272/PE. Relator: Ministro Franciulli Netto. Julgamento: 09 ago. 2005. Órgão Julgador: Segunda Turma. Publicação: DJ, 21 mar. 2006.

. Superior Tribunal de Justiça. Recurso Especial 742.768/SP. Relator: Ministro Teori Albino Zavascki. Órgão Julgador: Primeira Turma. Data do Julgamento: 02 fev. 2006. Data da Publicação: DJ 20 fev. 2006.

. Superior Tribunal de Justiça. Recurso Especial 749.593/RJ. Relator: Ministro Teori Albino Zavascki. Julgamento: 16 set. 2007. Órgão Julgador: Primeira Turma. Publicação: DJ, 08 out. 2007;

. Superior Tribunal de Justiça. Recurso Especial 798.166/RJ. Relator: Ministro Herman Benjamin. Julgamento: 12 fev. 2008. Órgão Julgador: Segunda Turma. Publicação: DJe, 29 ago. 2008.

. Superior Tribunal de Justiça. Recurso Especial 799.564/PE. Relator: Ministro Teori Albino Zavaski. Julgamento: 18 out. 2007. Órgão Julgador: Primeira Turma. Publicação: DJU, 05 nov. 2007.

. Superior Tribunal de Justiça. Recurso Especial 815.738/SP. Relator: Ministro Teori Albino Zavascki. Julgamento: 09 out. 2007. Órgão Julgador: Primeira Turma. Publicação: DJ, 25 out. 2007;

- Superior Tribunal de Justiça. Recurso Especial 817.323/CE. Relator: Ministro Teori Albino Zavascki. Julgamento: 6 abr. 2006. Órgão Julgador: Primeira Turma. Publicação: DJ, 24 abr. 2006.

. Superior Tribunal de Justiça. Recurso Especial 840.666/PA. Relator: Ministro Francisco Falcão. Julgamento: 14 ago. 2006. Órgão Julgador: Primeira Turma. Publicação: DJ, 31 ago. 2006;

- Superior Tribunal de Justiça. Recurso Especial 891.758/SP. Relatora: Ministra Eliana Calmon. Julgamento: 07 out. 2008. Órgão Julgador: Segunda Turma. Publicação: DJe, 04 nov. 2008.

. Superior Tribunal de Justiça. Recurso Especial 903.394/AL. Relator: Ministro Luiz Fux. Julgamento: 24 mar. 2010. Órgão Julgador: Primeira Seção. Publicação: DJe, 26 abr. 2010.

Superior Tribunal de Justiça. Recurso Especial 928.875/MT. Relator: Ministro Herman Benjamin. Julgamento: 11 maio 2010. Órgão Julgador: Segunda Turma. Publicação: DJe, 01 jul. 2010. 
. Superior Tribunal de Justiça. Recurso Especial 935.311/SP. Relatora: Ministra Eliana Calmon. Julgamento: 26 ago. 2008. Órgão Julgador: Segunda Turma. Publicação: DJe, 18 set. 2008.

. Superior Tribunal de Justiça. Recurso Especial 935.889/SP. Relator: Ministro Mauro Campbell Marques. Órgão Julgador: Segunda Turma. Publicação: DJe, 27 set. 2010 .

- Superior Tribunal de Justiça. Recurso Especial 961.178/RS. Relatora: Ministra Eliana Calmon. Julgamento: 07 maio 2009. Órgão Julgador: Segunda Turma. Publicação: DJe, 25 maio 2009.

. Superior Tribunal de Justiça . Recurso Especial 1.082.690/SP. Relator: Luiz Fux. Julgamento: 27 out. 2009. Órgão Julgador: Primeira Turma. Publicação: DJe 02 fev. 2010.

Superior Tribunal de Justiça. Súmula 461. O contribuinte pode optar por receber, por meio de precatório ou por compensação, o indébito tributário certificado por sentença declaratória transitada em julgado. Brasília: DJe, 08 set. 2010.

Superior Tribunal de Justiça. Súmula $n^{\circ} 188$. Os juros moratórios, na repetição do indebito tributário, são devidos a partir do transito em julgado da sentença. Julgamento: 11 jun. 1997. Órgão Julgador: Primeira Seção. Publicação: DJ, 23 jun. 1997.

. Superior Tribunal de Justiça. Recurso Especial 982.985. Relator: Ministro Luiz Fux. Julgamento: 10 jun. 2008. Órgão Julgador: Primeira Turma. Publicação: DJe, 07 ago. 2008.

. Superior Tribunal de Justiça. Embargos de Divergência no Recurso Especial 463.167/SP. Relator: Ministro Teori Zavascki. Julgamento: 13 abr. 2005. Órgão Julgador: Primeira Seção. Publicação: 02 maio 2005.

Supremo Tribunal Federal. Ação Direta de Inconstitucionalidade 15/DF. Relator: Ministro Sepúlveda Pertence. Julgamento: 14 jun. 2007. Órgão Julgador: Tribunal Pleno. Publicação: DJ, 21 jun. 2007.

. Supremo Tribunal Federal. Ação Direta de Inconstitucionalidade 2.154/DF. Relator: Ministro Dias Toffoli. Julgamento: 18 ago. 2007. Órgão Julgador: Tribunal Pleno. Publicação: DJ, 11 set. 2007.

. Supremo Tribunal Federal. Ação Direta de Inconstitucionalidade 2.258. Relator: Ministro Dias Toffoli. Julgamento: 16 ago. 2007. Órgão Julgador: Tribunal Pleno. Publicação: Dj, 11 set. 2007.

. Supremo Tribunal Federal. Ação Direta de Inconstitucionalidade 1.1022/DF. Relator: Ministro Maurício Corrêa. Julgamento: 05 out. 1995. Órgão Julgador: Tribunal Pleno. Publicação: DJU, 17 nov. 1995.

. Supremo Tribunal Federal. Ação Rescisória 1.239/MG. Relator: Ministro Carlos Madeira. Julgamento: 31 ago. 1988. Órgão Julgador: Tribunal Pleno. Publicação: DJ 30 ago. 1990. 
. Supremo Tribunal Federal. Agravo de Instrumento 686.655/RJ. Relator: Ministro Ricardo Lewandowski. Julgamento: 27 mai. 2008. Órgão Julgador: Primeira Turma. Publicação. Dje 13 jun. 2008.

Supremo Tribunal Federal. Agravo Regimental no Agravo de Instrumento 598.528/MG. Relator: Ministro Carmen Lúcia. Julgamento: 06 jun. 2011. Órgão Julgador: Decisão Monocrática. Publicação: DJ, 21 jun. 2011.

Supremo Tribunal Federal. Agravo Regimental no Recurso Extraordinário 234.995/SP. Relator: Ministro Dias Toffoli. Julgamento: 03 dez. 2010. Órgão Julgador: Decisão Monocrática. Publicação: DJ, 21 fev. 2011.

Supremo Tribunal Federal. Agravo Regimental no Recurso Extraordinário 391.793/SC. Relator: Ministro Carmen Lúcia. Julgamento: 01 jun. 2011. Órgão Julgador: Decisão Monocrática. Publicação: DJ, 13 jun. 2011.

Supremo Tribunal Federal. Agravo Regimental no Recurso Extraordinário 590.659/PR. Relator: Ministro Dias Toffoli. Julgamento: 15 set. 2010. Órgão Julgador: Decisão Monocrática. Publicação: DJ 08 nov. 2010.

- Supremo Tribunal Federal. Embargo de Declaração no Recurso Extraordinário 614.358/SE. Relator: Ministro Carmen Lúcia. Julgamento: 05 nov. 2010. Órgão Julgador: Decisão Monocrática. Publicação: DJ, 25 nov. 2010.

- Supremo Tribunal Federal. Reclamação 1.987/DF. Relator: Ministro Maurício Corrêa. Julgamento: 01 out. 2003. Órgão Julgador: Tribunal Pleno. Publicação: DJ, 21 maio 2004.

. Supremo Tribunal Federal. Reclamação 2.363/PA. Relator: Ministro Gilmar Mendes. Julgamento: 05 nov. 2003. Órgão Julgador: Tribunal Pleno. Publicação: DJ, 01 abr. 2005.

. Supremo Tribunal Federal. Recurso Extraordinário 45.977/ES. Relator: Ministro Aliomar Baleeiro. Julgamento: 27 set. 1966. Órgão Julgador: Segunda Turma. Publicação: 22 fev. 1967.

. Supremo Tribunal Federal. Recurso Extraordinário 46.450/RS. Relator: Ministro Antonio Villas Boas. Julgamento: 10 jan. 1961. Órgão Julgador: Segunda Turma. Publicação: Dj 02 jun. 1961.

Supremo Tribunal Federal. Recurso Extraordinário 148.754.2/RJ. Relator: Ministro Francisco Rezek. Julgamento: 24 jun. 1993. Órgão Julgador: Tribunal Pleno. Publicação: DJ, 04 mar. 1994.

Supremo Tribunal Federal. Recurso Extraordinário 103.619-2. Relator: Ministro Oscar Dias Corrêa. Julgamento: 02 fev. 1985. Órgão Julgador: Tribunal Pleno. Publicação: DJU, 15 mar. 1985.

. Supremo Tribunal Federal. Recurso Extraordinário 121.336/CE. Relator: Ministro Sepúlveda Pertence. Julgamento: 17 out. 1990. Órgão Julgador: Tribunal Pleno. Publicação: 26 jun. 1992. 
. Supremo Tribunal Federal. Recurso Extraordinário 363.852/MG. Relator: Ministro Marco Aurélio. Julgamento: 3 fev. 2010. Órgão Julgador: Tribunal Pleno. Publicação: DJe 23 abr. 2010.

. Supremo Tribunal Federal. Recurso Extraordinário 172.058/SC. Relator: Ministro Marco Aurélio. Julgamento: 30 jun. 1995. Órgão Julgador: Tribunal Pleno, Publicação DJ 13 out. 1995.

. Supremo Tribunal Federal. Recurso Extraordinário 598.037/RS. Relator: Ministra Carmen Lúcia. Julgamento: 20 jun. 2011. Órgão Julgador: Decisão Monocrática. Publicação: DJ, 02 ago. 2011.

Supremo Tribunal Federal. Recurso Extraordinário 608.552/AL. Relator: Ministro Dias Toffoli. Julgamento: 29 mar. 2011. Órgão Julgador: Decisão Monocrática. Publicação: DJ, 07 abr. 2011.

. Supremo Tribunal Federal. Recurso Extraordinário 33.146. Relator: Ministro Afrânio Costa. Julgamento: 28 jan. 1958. Órgão Julgador: Segunda Turma. Publicação: 14 maio 1958.

. Supremo Tribunal Federal. Recurso Extraordinário 84.755/SP. Relator: Ministro Moreira Alves. Julgamento: 12 ago. 1976. Órgão Julgador: Segunda Turma. Publicação: DJ 17 set. 1976.

. Supremo Tribunal Federal. Recurso Extraordinário 89.402. Relator: Ministro Leitão de Abreu. Julgamento: 23 fev. 1979. Órgão Julgador: Segunda Turma. Publicação: DJ 06 abr. 1979.

. Supremo Tribunal Federal. Recurso Extraordinário 92.401/SP. Relator: Ministro Thompson Flores. Julgamento: 08 abr. 1980. Órgão Julgador: Primeira Turma. Publicação: DJ, 16 maio 1980.

. Supremo Tribunal Federal. Recurso Extraordinário 92.671. Relator: Ministro Rafael Mayer. Julgamento: 24 jun. 1980. Órgão Julgador: Primeira Turma. Publicação: DJ, 12 ago. 1980.

. Supremo Tribunal Federal. Recurso Extraordinário 92.742. Relator: Ministro Décio Miranda. Julgamento: 05 maio 1981. Órgão Julgador: Segunda Turma. Publicação: DJ, 29 maio 1981.

- Supremo Tribunal Federal. Recurso Extraordinário 94.935/RJ. Relator: Ministro Rafael Mayer. Julgamento: 29 set. 1981. Órgão Julgador: Primeira Turma. Publicação: DJ 23 out. 1983.

. Supremo Tribunal Federal. Recurso Extraordinário 96.808/RJ. Relator: Ministro Cordeiro Guerra. Julgamento: 27 abr. 1982. Órgão Julgador: Segunda Turma. Publicação: DJ, 11 jun. 1982.

Supremo Tribunal Federal. Recurso Extraordinário 99.458/SP. Relator: Ministro Francisco Rezek. Julgamento: 30 set. 1983. Órgão Julgador: Segunda Turma. Publicação: 27 out. 1983. 
. Supremo Tribunal Federal. Recurso Extraordinário 136.806/SP. Relator: Moreira Alves. Julgamento: 07 maio 1991. Publicação: 24 maio 1991.

. Supremo Tribunal Federal. Recurso Extraordinário 136.883-7. Relator: Ministro Sepúlveda Pertence. Julgamento: 27 ago. 1991. Órgão Julgador: Primeira Turma. Publicação: DJ, 13 set. 1991.

. Supremo Tribunal Federal. Recurso Extraordinário n. 136.883/RJ. Relator: Ministro Sepúlveda Pertence. Julgamento: 27 ago. 1991. Órgão Julgador: Segunda Turma. Publicação: DJ 30 ago. 1991.

. Supremo Tribunal Federal. Recurso Extraordinário n. 138.284-CE. Relator: Ministro Carlos Velloso. Julgamento: 01 jul. 1992. Órgão Julgador: Tribunal Pleno. Publicação: DJ 28 ago. 1992.

. Supremo Tribunal Federal. Recurso Extraordinário n. 141.331/RJ. Relator: Ministro Paulo Brossard. Julgamento: 19 abr. 1994. Órgão Julgador: Segunda Turma. Publicação: 10 maio 1994.

Supremo Tribunal Federal. Recurso Extraordinário 143.677/RJ. Relator: Ministro Carlos Velloso. Julgamento: 10 mar 1992. Órgão Julgador: Segunda Turma. Publicação: 13 mar. 1992.

- Supremo Tribunal Federal. Recurso Extraordinário 145.787/RJ. Relator: Ministro Ilmar Galvão. Julgamento: 14 abr. 1992. Órgão Julgador: Primeira Turma. Publicação: 23 abr. 1992.

. Supremo Tribunal Federal. Recurso Extraordinário 166.772-9/RS. Relator: Ministro Marco Aurélio. Julgamento: 12 maio 1994. Órgão Julgador: Tribunal Pleno. Publicação: DJU, 20 maio 1994.

- Supremo Tribunal Federal. Recurso Extraordinário 167.992/PR. Relator: Ministro Ilmar Galvão. Julgamento: 23 nov. 1994. Órgão Julgador: Tribunal Pleno. Publicação: DJ 02 dez. 1994.

. Supremo Tribunal Federal. Recurso Extraordinário 226.855-7/RS. Relator: Ministro Moreira Alves. Julgamento: 31 ago. 2000. Órgão Julgador: Tribunal Pleno. Publicação: DJ, 13 out. 2000.

. Supremo Tribunal Federal. Recurso Extraordinário 240.785/MG. Relator: Ministro Marco Aurélio. Julgamento: 08 jun. 2011. Órgão Julgador: Decisão Monocrática. Publicação: 01 ago. 2011.

. Supremo Tribunal Federal, Recurso Extraorinário 353.657/PR. Relator: Ministro Marco Aurélio. Julgamento: 25 jun. 2007. Órgão Julgador: Tribunal Pleno. Publicação 07 mar. 2008

. Supremo Tribunal Federal. Recurso Extraordinário 559.943/RS. Relatora: Ministra Cármen Lúcia. Julgamento: 12 jun. 2008. Órgão Julgador: Tribunal Pleno. Publicação: DJe, 14 ago. 2008. 
. Supremo Tribunal Federal. Recurso Extraordinário 565.089/SP. Relator: Ministro Marco Aurélio. Julgamento: 14 nov. 2008. Órgão Julgador: Decisão Monocrática. Publicação: DJ, 10 dez. 2008.

. Supremo Tribunal Federal. Súmula $n^{\circ} 150$. Prescreve a execução no mesmo prazo de prescrição da ação. Aprovação: Plenária, 13 dez. 1963. Brasília: Imprensa Nacional, 1964, p. 84. (Súmula da Jurisprudência Predominante do Supremo Tribunal Federal - Anexo ao Regimento Interno).

Supremo Tribunal Federal. Súmula $n^{\circ}$ 343. Não cabe ação rescisória por ofensa a literal disposição de lei, quando a decisão rescindenda se tiver baseado em texto legal de interpretação controvertida nos tribunais. Aprovação: Plenária, 13 dez. 1963. Brasília: Imprensa Nacional, 1964, p. 150 (Súmula da Jurisprudência Predominante do Supremo Tribunal Federal - Anexo ao Regimento Interno).

Supremo Tribunal Federal. Súmula $n^{\circ}$ 360. O benefício da denúncia espontânea não se aplica aos tributos sujeitos a lançamento por homologação regularmente declarados, mas pagos a destempo. Julgamento: 27 ago. 2008. Órgão Julgador: Primeira Seção. Publicação: DJe 08 set. 2008.

. Supremo Tribunal Federal. Recurso Extraordinário 370.682/SC. Relator: Ministro Ilmar Galvão. Julgamento: 25 jun. 2007. Órgão Julgador: Tribunal Pleno. Publicação DJe 19 dez. 2007

. Supremo Tribunal Federal. Súmula $n^{\circ}$ 546, de 03 de dezembro de 1969. Cabe a restituição do tributo pago indevidamente, quando reconhecido por decisão, que o contribuinte "de jure" não recuperou do contribuinte "de facto" o "quantum" respectivo. Brasília: DJ 10 dez. 1969, p. 5935; DJ 11 dez. 1969, p. 5951; DJ 12 dez. 1969, p. 5999.

. Tribunal Federal de Recursos. Súmula 46. Nos casos de devolução do depósito efetuado em garantia de instância e de repetição do indébito tributário, a correção monetária e calculada desde a data do depósito ou do pagamento indevido e incide até o efetivo recebimento da importância reclamada. Brasília: DJ, 14 out. 1980.

. Supremo Tribunal Federal. Questão de Ordem no Agravo de Instrumento $\overline{760.350 / S E}$. Relator: Ministro Gilmar Mendes. Publicação: DJ, 19 fev. 2010.

Bueno, Cássio Scarpinella. Curso Sistematizado de Direito Processual Civil - Tutela jurisdicional executiva. 3. ed.São Paulo: Saraiva, 2010.

BuZAID, Alfredo. Da ação direta de declaração de inconstitucionalidade no direito brasileiro. São Paulo: Saraiva, 1958.

CAIs, Cleide Previtalli. O Processo Tributário. 4. ed. São Paulo: Editora Revista dos Tribunais, 2004.

CANTO, Gilberto Ulhôa. Repetição do Indébito. In: MARTins, Ives Gandra (Coord.). Cadernos de Pesquisas Tributárias $n^{\circ} 8$ - Repetição do Indébito. São Paulo: Editora Resenha Tributária, 1983, p. $1-16$. 
Cappelletti, Mauro. O Controle Judicial de Constitucionalidade das Leis no Direito Comparado. 2. ed. Porto Alegre: Fabris, 1984.

Carrazza, Roque. Direito Constitucional Tributário. São Paulo: Malheiros, 2009.

. ICMS. 16. ed. São Paulo: Malheiros, 2012.

Carvalho, Aurora Tomazini de. Curso de Teoria Geral do Direito - O Constructivismo Lógico Semântico. São Paulo: Noeses, 2009.

Carvalho, Paulo de Barros. Curso de Direito Tributário. 22. ed. São Paulo: Saraiva, 2010.

- Derivação e Positivação no Direito Tributário. São Paulo: Noeses, $2011 / 2012$.

. Direito Tributário, linguagem e método. São Paulo: Noeses, 2009.

. Fundamentos Jurídicos da Incidência. 8. ed. São Paulo: Saraiva. 2010.

. Para uma teoria da norma jurídica.

Disponível em http://www.barroscarvalho.com.br/art_nac/teoria norma.pdf.

- O Princípio da Segurança Jurídica no Campo do Direito Tributário. In: Revista de Direito Tributário n ${ }^{\circ}$ 94, p. 21 - 30.

CASTRO, Rodrigo R. Monteiro de. Legitimidade para pedir a restituição do indébito tributário em decorrência de operações de transformação, incorporação, fusão e aquisição. In: CEZAROTI, Guilherme (Coord.). Repetição de Indébito Tributário. São Paulo: Quartier Latin, 2005, p. 197 - 223.

Cavalcanti, Amaro. Responsabilidade Civil do Estado. Tomo II, Rio de Janeiro: Editor Borsoi, 1957.

Cavalcanti, Themístocles Brandão. Do contrôle da Constitucionalidade. Rio de Janeiro: Forense, 1966.

Cerqueira, Marcelo Fortes de. Repetição de Indébito Tributário. São Paulo: Max Limonad. 2000.

. Extinção da obrigação Tributária: Compensação e Repetição de Indébito. In: SANTI, Eurico Marcos Diniz de (Coord.). Curso de Especialização em Direito Tributário - Homenagem ao Professor Paulo de Barros Carvalho, Rio de Janeiro: Forense, 2006, p. 372-434.

Cerezo, Rafael Mateu-Ros. Devolución de ingresos tributarios indebidos y revisión por infracción de ley. Madrid: Civitas, 1985.

Cezaroti, Guilherme. Decisão judicial transitada em julgado. Tributo declarado inconstitucional. Desconsideração da coisa julgada pelo Conselho de Contribuintes. In: (Coord.). Repetição de Indébito Tributário. São Paulo: Quartier Latin, 2005, p. 99 - 134. 
Chiavegatti, Ricardo. Coisa julgada: análise das sentenças contrárias à Constituição, no âmbito do sistema jurídico brasileiro. Dissertação de Mestrado - Universidade de São Paulo (USP), 2006.

Cintra, Antônio Carlos Araújo; Dinamarco, Cândido Rangel; Grinover, Ada Pellegrini. Teoria Geral do Processo. 28. ed. São Paulo: Malheiros, 2012.

Clève, Emerson Merlin A fiscalização abstrata de constitucionalidade no Direito brasileiro. São Paulo, RT, 1995.

CoÊLHO, Sacha Calmon Navarro. A modulação dos efeitos temporais das decisões constitucionais em matéria tributária. In: RochA, Valdir de Oliveira (Coord.). Grandes Questões Atuais do Direito Tributário, $12^{\circ}$ volume. São Paulo: Dialética, 2008, p. 463-476.

. Curso de Direito Tributário Brasileiro. 10. ed. Rio de Janeiro: Forense, 2009.

CoÊLHo, Sacha Calmon Navarro; e DerzI, Misabel Abreu Machado. ICMS - Direito ao Creditamento - Princípio da Não-Cumulatividade. Revista Dialética de Direito Tributário $\mathrm{n}^{\mathrm{o}}$ 102, março - 2004, p. 141 - 156.

Conrado, Paulo César. Compensação Tributária e Processo. São Paulo: Quartier Latin. 2009.

. Processo Tributário. 2. ed. São Paulo: Quartier Latin, 2007.

. Repetição de Indébito Tributário: definição, condições e efeitos. In: CEZAROTI, Guilherme (Coord.). Repetição de Indébito Tributário. São Paulo: Quartier Latin, 2005, p. 13-20.

Conrado, Paulo Cesar e SAnTi, Eurico Marcos Diniz de. Controle direto de constitucionalidade e repetição do indébito tributário. Revista Dialética de Direito Tributário - n. 86 nov. 2002, p. 27-33.

Costa, Maria Cristina Roza da. O limite temporal para o exercício do direito de repetição de indébito em face da decisão de inconstitucionalidade. In: TORRES, Heleno Taveira; QueIroz, Mary Elbe e FeITosA, Raymundo Juliano (Coords.). Direito tributário e processo administrativo aplicados. São Paulo: Quartier Latin, 2005, p. 128-175.

Cretella Júnior, José. O Estado e a Obrigação de Indenizar. Rio de Janeiro: Forense, 1998.

CruZ, Célio Rodrigues da. Manutenção e Transferência de Crédito de ICMS. Revista de Estudos Tributários, Ano XII - no 69 - setembro/outubro 2009, p. 7 - 17.

Dallazem, Dalton Luiz. Inconstitucionalidade e Tributo. São Paulo: Quartier Latin, 2010 .

DARZÉ, Andréa Medrado. Responsabilidade Tributária - Solidariedade $e$ Subsidiaridade. São Paulo: Noeses, 2010. 
DerzI, Misabel de Abreu Machado. Distorções do Princípio da Não-Cumulatividade no ICMS - comparação com o IVA europeu. In: Temas de Direito Tributário, I Congresso Nacional da Associação Brasileira de Direito Tributário, Belo Horizonte, Livraria Del Rey, 1998, p. 1074 - 151.

. Modificações da Jurisprudência no Direito Tributário. São Paulo: Noeses, 2009.

. Aspectos Essenciais do ICMS como imposto de mercado. In: SCHOUERI, Luis Eduardo; ZilveTI, Fernando Aurelio (Coords.). Estudos a Homenagem de Brandão Machado, São Paulo: Dialética, 1998, p. 116 - 142.

DenARI, Zelmo. Repetição dos tributos indiretos. In: MARTINS, Ives Gandra (Coord.). Caderno de Pesquisas Tributárias $n^{\circ}$ 8. São Paulo: Centro de Estudos de Extensão Universitária e Editora Resenha Tributária, 1983, p. 133-134.

Didier Junior, Fredie. Curso de Direito Processual Civil - Execução - Volume 5, 2. ed. Salvador: Jus Podivm, 2010.

Dinamarco, Cândido Rangel. Instituições do Direito Processual Civil IV, 3. ed. São Paulo: Malheiros, 2009.

DINIZ, Marcelo de Lima Castro. Substituição Tributária e Repetição de Indébito: legitimidade processual. Disponível em: http://www.idtl.com.br/artigos/359.pdf.

Diniz, Marcelo de Lima Castro; PeIXото, Marcelo Magalhães. A regra do artigo 166 do Código Tributário Nacional e a sua Aplicação à Cofins - não cumulativa e ao Pis não cumulativo, in CeZAROTI, Guilherme (Coord.). Repetição de Indébito Tributário. São Paulo: Quartier Latin, 2005, p. 287 - 315.

. Nova Era do Processo Civil, 3. ed. São Paulo: Malheiros, 2009.

DworkIn, Ronald. The Model of Rules I, in Id., Taking Rights Seriously, London, Duckworth, 1977, excerpts p. 17-28.

Esteves, Júlio César dos Santos. Responsabilidade Civil do Estado por Ato Legislativo. Belo Horizonte: Delrey, 2003.

FALCÃo, Amílcar de Araújo. Introdução ao Direito Tributário. 4. ed. Rio de Janeiro: Forense, 1993.

FERNANDES, Luis Dias. Repetição de indébito tributário - o inconstitucional artigo 166 do CTN. Rio de Janeiro: Renovar, 2002.

Ferraz Junior, Tércio Sampaio. Introdução ao Estudo do Direito, 8. ed. São Paulo: Atlas, 2008.

FERrari, Regina Maria Macedo Nery. Direito Constitucional. São Paulo: Revista dos Tribunais, 2011.

FERreIRA, Camila Quintão. Prazo para a repetição do indébito tributário com supedâneo em lei inconstitucional. Revista de Direito Tributário da APET - v. 3 n. 10 jun. 2006 , p. 55-82. 
Ferreira, Antonio Airton. Prazo para repetição de tributo considerado indevido porque cobrado com base em lei declarada inconstitucional pelo STF - ato declaratório do Secretario da Receita Federal n. 96/99. Panorama da Justiça v. 5 n. 30 jul./ago. 2001, p. 60-62.

Ferreira Filho, Manuel Gonçalves. Curso de Direito Constitucional. 32. ed. São Paulo: Saraiva, 2006.

Figueiredo, Lúcia Valle; Balera, Wagner; e Lopes Neto, Osíris de Azevedo. Processo Administrativo Tributário e Controle de Constitucionalidade pelos Tribunais Administrativos. Revista de Direito Tributário $\mathrm{n}^{\mathrm{o}} 75$, Malheiros, 1999, p. 151-161.

FLuSSER, Vilém. Língua e Realidade, São Paulo: Editôra Herder, 1963.

Franciulli NetTo, Domingos. Tributos declarados inconstitucionais pelo Supremo Tribunal Federal: da prescrição e da vedação aos limites à compensação. Revista Fórum de Direito Tributário, Belo Horizonte, v. 2, n. 12, nov. 2004. Disponível em: <http://bdjur.stj.gov.br/dspace/handle/2011/326>.

FRATTARI, Rafhael. Os prazos para a restituição do indébito no direito brasileiro teoria e prática. Belo Horizonte: Editora Líder, 2010.

Freitas, Leonardo e Silva de Almendra. Análise crítica da reviravolta da orientação do STJ acerca da legitimidade do contribuinte "de fato" para repetir o indébito tributário indireto. Revista Dialética de Direito Tributário, São Paulo, n, 187, abr. 2011, p. 96-111.

FREIRE JÚNIOR, Américo Bedê. Os efeitos da declaração de inconstitucionalidade das leis no prazo de decadência para a ação de repetição de indébito tributário. Revista Tributária e de Finanças Públicas - v. 10 n. 44 maio-jun. 2002, p. 8388 .

Galeski Junior, Irineu. A análise econômica do Direito e a Repetição do indébito tributário. Dissertação apresentada para obtenção do título de Mestrado PUC-PR.

GAMA, Tácio Lacerda. Competência Tributária - Fundamentos para uma teoria da nulidade. São Paulo: Noeses, 2009.

- Teoria Dialógica da validade - Existência, regularidade e efetividade das normas tributárias. In: Vilém Flusser e Juristas - comemoração dos 25 anos de grupo de estudos de Paulo de Barros Carvalho. Jerson e HARET, Florence (Coords.). São Paulo: Noeses, 2010.

GRAU, Eros Roberto. Ensaio e discurso sobre a interpretaçãolaplicação do Direito. 3. ed. São Paulo: Malheiros, 2005.

- Responsabilidade do Estado em matéria tributária, Revista de Direito Tributário - 43, 1988, p. 132 - 143.

Greco, Marco Aurélio; Pontes, Helenilson Cunha. Inconstitucionalidade da lei tributária - repetição de indébito. São Paulo: Dialética, 2002. 
GonÇALVES, José Arthur de Lima. O direito à restituição do indébito tributário. In: MaCHADO, Hugo de Brito (Coord.). Repetição do Indébito e Compensação no Direito Tributário. São Paulo: Dialética; Fortaleza: Instituto Cearense de Estudos Tributário, 1999, p. 198 - 231.

Guerrero, Luis Corral. El Derecho del contribuyente a la devolución de impuestos (introducción a una teoría general). Madrid: Revista de Derecho Privado, 1977.

HART, Herbert L. A., O Conceito de Direito. São Paulo: Martins Fontes, 2009.

Ivo, Gabriel. A incidência da norma jurídica. O cerco da linguagem. Revista de Direito Tributário $\mathrm{n}^{\circ} 79$.

Kelsen, Hans. General Theory of Norms, Engl. Trans., Oxford, Clarendon Press, 1991, Ch. 1, 15, 25.

. Introduction to the Problems of Legal Theory, Engl. Trans., Oxford: Clarendon Press, 1992, Ch. 5.

. Jurisdição Constitucional. São Paulo: Martins Fontes, 2003.

. Teoria Pura do Direito. 5. ed. São Paulo: Martins Fontes, 2003.

Krakowiak, Leo. Repetição do Indébito. In: MARTins, Ives Gandra (Coord.). Caderno de Pesquisas Tributárias $n^{\circ}$ 8. São Paulo: Centro de Estudos de Extensão Universitária e Editora Resenha Tributária, 1983, p. 195 - 220.

LarenZ, Karl. Metodologia da ciência do direito. 6. ed. Lisboa: Fundação Calouste Gulbenkian, 2012.

Laurentis, Lucas Catib de. Controle de Constitucionalidade pela Administração. Revista de Direito Administrativo, Rio de Janeiro, v. 260, p. 133-166, maio/ago. 2012, p. $133-166$.

LAURENTIIS, Thais Catib de. Embargos à Execução, coisa julgada e inconstitucionalidade: uma análise das questões controvertidas acerca do art. 741, parágrafo único do Código de Processo Civil. Revista Dialética de Direito Processual n. 118, jan. 2013, p. $127-151$.

LEAL, Roger Stiefelmann. A incorporação das súmulas vinculantes à jurisdição constitucional brasileira: alcance e efetividade em face do regime legal da repercussão geral e da proposta de revisão jurisprudencial sobre a interpretação do art. 52, X, da Constituição. RDA - Revista de Direito Administrativo Belo Horizonte, ano 2012, n. 261, set. / dez. 2012, p 179 - 201.

LeÃo, Celina Gontijo; Urbano, Evo Magro Corrêa Urbano. A relativização da coisa julgada dos artigos 475-L e 741, parágrafo único do CPC, Revista Dialética de Direito Processual, n. 93, p. $24-35$.

LINS, Robson Maia. Controle de Constitucionalidade da Norma Tributária. São Paulo: Quartier Latin, 2005. 
LuCon, Paulo Henrique dos Santos. Coisa julgada, efeitos da sentença, "coisa julgada inconstitucional" e embargos à execução do artigo 741, parágrafo único. Revista do Advogado, n. 84, ano XXV, dezembro 2005, p. 146 - 164.

Machado, Brandão. Repetição do indébito no direito tributário. In: (Org.). Direito Tributário - estudos em homenagem ao Prof. Ruy Barbosa Nogueira. São Paulo: Saraiva, 1994, p. 59 - 106.

Machado, Hugo de Brito. Apresentação e análise crítica. In: (Coord.). Repetição do Indébito e Compensação no Direito Tributário. São Paulo: Dialética; Fortaleza: Instituto Cearense de Estudos Tributário, 1999, p. 7 - 32. . Comentários ao Código Tributário Nacional - artigos 139 a 218 - Volume III. São Paulo: Atlas, 2005.

. Curso de Direito Tributário. 30. ed. São Paulo: Malheiros, 2009.

Machado Segundo, Hugo de Brito. Repetição do Indébito Tributário Indireto: incoerências e contradições. São Paulo: Malheiros, 2011.

MARCílio, Carlos Flávio Venâncio. Declaração de inconstitucionalidade no controle concentrado e repetição do indébito tributário. Revista Tributária e de Finanças Públicas - v. 16 n. 79 mar./ abr. 2008, p. 75-97.

Marinoni, Luiz Guilherme; Mitidiero, Daniel, Código de Processo Civil comentado artigo por artigo. 2. ed. São Paulo: Editora Revista dos Tribunais, 2010.

MarinOnI, Luiz Guilherme. Coisa julgada Inconstitucional. São Paulo: RT, 2008.

Marins, James. O Direito Processual Tributário, 5. ed. São Paulo: Dialética, 2010.

MARTINs, Ives Gandra da Silva. Efeito prospectivo de decisões da Suprema Corte sobre matéria constitucional - Sua admissibilidade tanto em controle concentrado quanto em controle difuso - Parecer Revista Forense - v. 103 n. 389 jan./ fev. 2007: Forense, 2007, p. 207-220.

MARTINS, Ives Gandra da Silva. Repetição do Indébito. (Coord.). In: Caderno de Pesquisas Tributárias $n^{\circ}$ 8. São Paulo: Centro de Estudos de Extensão Universitária e Editora Resenha Tributária, 1983.

MARTINs, Natanael. Correção monetária na compensação/ repetição de indébito (tentativa de solução dos equívocos e omissões que vêm sendo cometidos em decisões judiciais). In Revista dos Tribunais, ano 4, n. 13, out./dez. 1995, p. 111-116.

MASIERO, João Gustavo Bachega. Legitimados à restituição do indébito na substituição tributária para frente. Revista Tributária e de Finanças Públicas v. 15 n. 74 maio/ jun. 2007: Revista dos Tribunais, 2007, p. 44-63.

Maximiliano, Carlos. Hermenêutica e Aplicação do Direito. 19. ed. Rio de Janeiro: Editora Forense, 2008.

Mattos, Aroldo Gomes de. Repetição do Indébito, Compensação e Ação Declaratória, in MACHAdo, Hugo de Brito (Coord.). Repetição do Indébito e 
Compensação no Direito Tributário. São Paulo: Dialética; Fortaleza: Instituto Cearense de Estudos Tributário, 1999, p. 47 - 53.

Medeiros, Rui. A decisão de Inconstitucionalidade: os autores, o conteúdo e os efeitos da decisão de inconstitucionalidade. Lisboa: Universidade Católica Editora, 1999.

Mello, Antônio Carlos de Martins. O Indébito Tributário e sua Recuperação. In: Machado, Hugo de Brito (Coord.). Repetição do Indébito e Compensação no Direito Tributário. São Paulo: Dialética; Fortaleza: Instituto Cearense de Estudos Tributário, 1999, p. 33 - 46.

Mello, Celso Antônio Bandeira de. Curso de Direito Administrativo, São Paulo: Malheiros, 2009.

Melo, José Eduardo Soares de. Repetição de Indébito. In: Martins, Ives (Coord.). Caderno de Pesquisas Tributárias $n^{\circ}$ 8. São Paulo: Centro de Estudos de Extensão Universitária e Editora Resenha Tributária, 1983, p. 253 - 275.

Mendes, Gilmar Ferreira. Curso de Direito Constitucional. São Paulo: Saraiva, 2009. . Direitos Fundamentais e Controle de Constitucionalidade. 3. ed. São Paulo: Saraiva, 2004.

MirandA, Dalton Cesar Cordeiro de. Coisa julgada judicial em face de pedidos administrativos de restituição elou compensação. Revista Tributária e de Finanças Públicas - v. 13 n. 63 jul./ ago. 2005: Revista dos Tribunais, 2005, p. 172-175.

Miranda, Francisco Cavalcante Pontes de. Tratado de Direito Privado. T. IV, atual. Campinas: Bookseller, 2000.

MirandA, Jorge. Contributo para uma teoria da inconstitucionalidade. Coimbra: Coimbra Editora, 2007.

Monteiro Neto, Nelson. Problemas de repetição do indébito. Revista Dialética de Direito Tributário - n. 104 maio 2004, p. 55-61.

MonteIro Neto, Nelson. Repetição do indébito tributário, por inconstitucional aplicabilidade da regra geral do art. $1^{\circ}$ do Decreto $n^{\circ} 20.910$, em vez das regras especiais do Código Tributário Nacional. IOB Repertorio de Jurisprudência Tributário, Constitucional e Administrativo - v. 1 n. 11 jun. 2004, p. 407-405.

Moraes, Alexandre de. Direito Constitucional. São Paulo: Atlas, 2006.

MoRCHÓN, Gregorio Robles. Teoria del derecho (fundamentos de teoría comunicacional del derecho). Madrid: Civitas, 1998.

MÖRSCHBÄCHER, José. Repetição do Indébito Tributário Indireto. São Paulo: Dialética, 1998. 
. Repetição do indébito tributário: avanços e retrocessos. Revista do Tribunal Regional Federal da 4. Região - v. 20 n. 71 jan./ mar. 2009. Porto Alegre: TRF 4. Região, 2009, p. 77-89.

- Restituição de tributos indevidos por compensação. Cadernos de Direito Tributário e Finanças Públicas - v. 3 n. 11 abr./ jun. 1995: Revista dos Tribunais, 1995, p. 70-74.

Moussallem, Tárek Moysés. Fontes do Direito Tributário. In: Santi, Eurico Marcos Diniz de (Coord.). Curso de Especialização em Direito Tributário Homenagem ao Professor Paulo de Barros Carvalho, Rio de Janeiro: Forense, 2006, p. 114.

. Revogação em Matéria Tributária. 2. ed. São Paulo: Noeses, 2011.

Mussolini JÚNIOR, Luiz Fernando, Extinção da Obrigação Tributária: processo administrativo e judicial, In SANTI, Eurico Marcos Diniz de (Coord.). Curso de Especialização em Direito Tributário-Homenagem ao Professor Paulo de Barros Carvalho, Rio de Janeiro: Forense, 2006, p. 408 - 434.

Nery Junior, Nelson e Nery, Rosa Maria de Andrade, Código de Processo Civil Comentado, 11. ed., São Paulo: RT, 2010.

Neves, Marcelo. Teoria da Inconstitucionalidade das Leis. São Paulo: Saraiva, 1988.

Neviani, Tarcisio. A restituição de tributos indevidos, seus problemas, suas incertezas. São Paulo: Resenha Tributária, 1983.

NogueIRA, Ruy Barbosa. Da interpretação e da aplicação das leis tributárias. Segunda edição, São Paulo: Editora Revista dos Tribunais, 1965.

. Curso de Direito Tributário. 5. ed. São Paulo: Saraiva, 1995.

NovoA, Cesar Garcia. La devolución de ingresos tributarios indebidos. Madrid: Instituto de Estudios Fiscales - Marcial Pons, 1993.

OliveIRA, Ricardo Mariz. Repetição do Indébito, Compensação e Ação Declaratória. In: Machado, Hugo de Brito (Coord.). Repetição do Indébito e Compensação no Direito Tributário. São Paulo: Dialética; Fortaleza: Instituto Cearense de Estudos Tributário, 1999, p. 335 - 398.

Pandolfo, Rafael. Jurisdição Constitucional Tributária. São Paulo: Noeses, 2012.

. Modulação de Efeitos em Matéria Tributária. In: CARvalho, Ana Carolina Papacosta de [et al.], Derivação e Positivação no Direito Tributário. São Paulo: Noeses, 2011.

Paulsen, Leandro. Direito Tributário - Constituição e Código Tributário à Luz da Doutrina e da Jurisprudência. 8. ed. Porto Alegre: Livraria do Advogado, 2006.

PereIRA, Caio Mário da Silva, Instituições de direito civil. vol. 1, 23 ${ }^{\mathrm{a}}$ ed. Rio de Janeiro: Forense, 2009, 
Perez, Fernando Augusto Martins. Os juros na repetição do indébito tributário. IOB Repertório de Jurisprudência Tributário, Constitucional e Administrativo - n. 4 fev. 2000, p. 105-111.

Pestana, Márcio. Inconstitucionalidade e Prescrição na Restituição do Tributo. Revista dos Tribunais - Ano 3, n. 12 - jul./set. 1995, p. 218 - 240.

PETRY, Rodrigo Caramori. A restituição de indébito tributário requerida em dinheiro na via administrativa: procedimento, aplicação de juros e decadência. Revista Tributária e de Finanças Públicas - v. 16 n. 80 maio-jun. 2008: Revista dos Tribunais, 2008, p. 159-188.

Pimenta, Paulo Roberto Lyrio. A declaração de inconstitucionalidade da norma jurídico-tributária como hipótese de repetição de indébito á luz da $L C n$. 118/05. In: RocHA, Valdir de Oliveira (Coord.). Grandes questões atuais do direito tributário: $9^{\circ}$ volume. São Paulo: Dialética, 2005. p. 430-442.

- A Modulação da Eficácia Temporal da Decisão de Inconstitucionalidade da Lei Tributária em Controle Difuso. In: ROCHA, Valdir de Oliveira (Coord.). Grandes Questões Atuais do Direito Tributário, $12^{\circ}$ volume. São Paulo: Dialética, 2008, p. 417-435.

. Efeitos da Decisão de Inconstitucionalidade no Direito Tributário. São Paulo: Dialética, 2002.

- Embargos à Execução e Decisão de Inconstitucionalidade - Relatividade da Coisa Julgada - CPC art. 741, parágrafo único - MP 2.180, Revista Dialética da Direito Processual n. 2, maio 2003, p. $99-107$.

- A restituição dos Tributos Inconstitucionais, o Novo Código Civil e a Jurisprudência do STF e do STJ, Revista Dialética de Direito Tributário - n. 91 abr. 2003, p. 90-95.

- Processo de Execução e Controle de Constitucionalidade (Embargos do Devedor e Exceção de Pré-Executividade), Revista Dialética de Direito Processual n. 6, p. $88-94$.

PIres, Adilson Rodrigues; TôRres, Heleno Taveira (Coords). Princípios de direito financeiro e tributário: estudos em homenagem ao Professor Ricardo Lobo Torres. Rio de Janeiro: Renovar, 2006.

PReSta, Sérgio. A devolução pelo Fisco de Valores Indevidos Originários de Sanções Pecuniárias Pagas Indevidamente. In: CEZAROTI, Guilherme (Coord.). Repetição de Indébito Tributário. São Paulo: Quartier Latin, 2005, p. 226 239.

QueIroz, Luis Cesar Souza de. Sujeição Passiva Tributária. 2. ed. São Paulo: Forense, 2003.

Ramos, Elival da Silva. Controle de Constitucionalidade no Brasil-perspectivas de evolução. São Paulo: Saraiva, 2010. 
Rodrigues, Walter Piva. A Regularidade da legitimação no ajuizamento da ação de repetição de indébito. In: CEZAROTI, Guilherme (Coord.). Repetição de Indébito Tributário. São Paulo: Quartier Latin, 2005. p. 86 - 98.

. Coisa julgada Tributária. São Paulo: Quartier Latin, 2008.

SABINo, Feres. $O$ prazo da repetição do indébito, em razão da lei declarada inconstitucional. Revista Dialética de Direito Tributário - n. 99 dez. 2003, p. 52-70.

Sampaio, Carlos César de Oliveira. Restituição de Imposto. São Paulo: S.N., 1921.

Santi, Eurico Marcos Diniz. Prescrição e Decadência no Direito Tributário. São Paulo: Max Limonad, 2004.

SILVA, Fabiana Carsoni A. Fernandes da. A prescrição da ação judicial voltada à restituição de indébito tem fluência desde o pagamento indevido, mesmo quando o sujeito passivo apresenta pedido administrativo de restituição? Revista Dialética de Direito Tributário - n. 171 dez. 2009. São Paulo: 2009, p. $35-47$.

Silva, José Afonso da. Curso de Direito Constitucional Positivo. 31. ed. São Paulo: Malheiros, 2008.

SCHOUERI, Luis Eduardo. Direito Tributário. São Paulo: Saraiva, 2011.

SouZA, Artur César de. Renúncia à prescrição e restituição de pagamento de crédito tributário prescrito: efeitos da súmula vinculante 8 do STF. Revista Tributária e de Finanças Públicas, Revista dos Tribunais, v. 16, n. 81, p. 36-48, jul./ago. 2008 .

Souza Junior, César Saldanha. Direito Constitucional: questões controvertidas. Porto Alegre: C.S, 2002.

SouzA, Rubens Gomes. Compêndio de legislação tributária. IBET, Instituto Brasileiro de Estudos Tributários (Coord.). Obra póstuma. São Paulo: Resenha Tributária, 1975.

Szlarowsky, Leon Fredja. A restituição do indébito na doutrina. In: MARTINS, Ives Gandra (Coord.). Caderno de Pesquisas Tributárias $n^{\circ}$ 8. São Paulo: Centro de Estudos de Extensão Universitária e Editora Resenha Tributária, 1983, p. $18-57$.

TAlamini, Eduardo. Embargos à Execução de Título Judicial Eivado de Inconstitucionalidade. Revista de Processo n. 106, Ano 27, abr./jun. 2002, p. $38-83$.

TAVARES. Alexandre Macedo. A responsabilidade Estatal pelo Desempenho Irregular da Função de Legislar como Engrenagem do Sistema de Freios e Contrapeses à Possibilidade de o STF atribuir Eficácia Prospectiva às Decisões de Inconstitucionalidade em Matéria Tributária. Revista Dialética de Direito Tributário $\mathrm{n}^{\mathrm{o}} 159$, dez - 2008, p. $7-18$. 
Tedesco, Paulo Camargo. A compensação como causa interruptiva do prazo para restituição do indébito. Revista Dialética de Direito Tributário - n. 169 out. 2009, p. 112-118.

Theodoro Junior, Humberto. A reforma do Processo de Execução e o problema da coisa julgada inconstitucional (Código de Processo Civil, artigo 741, parágrafo único). Revista dos Tribunais, ano 94, volume 841, novembro 2005, p. $56-76$.

. Curso de Direito Processual Civil. v. II, 45. ed., Rio de Janeiro, Forense, 2010.

TomÉ, Fabiana Del Padre. A prova no direito tributário. 2. ed. São Paulo: Noeses, 2008.

TORres, Heleno Taveira. Direito Constitucional Tributário e Segurança Jurídica. São Paulo: RT, 2011.

(Coord.). Tratado de direito constitucional tributário: estudos em homenagem a Paulo de Barros Carvalho. São Paulo: Saraiva, 2005.

TORRES, Ricardo Lobo. Normas de Interpretação e Integração do Direito Tributário. 4. ed. Rio de Janeiro: Renovar, 2006.

- O princípio da não cumulatividade e o IVA no direito comparado, in MARTINS, Ives Gandra da Silva (Coord.). O princípio da não-cumulatividade. São Paulo: Revista dos Tribunais, 2004, p. 139-170.

. Restituição de Tributos. Rio de Janeiro: Forense, 1983.

Troianelli, Gabriel Lacerda. Responsabilidade do Estado por Dano Tributário. São Paulo: Dialética, 2004.

. A ADI $n .15$ e a reabertura de prazos para repetição de indébito. Revista Dialética de Direito Tributário - n. 152 maio 2008, p. 81-92.

. Declaração de inconstitucionalidade e prazo para repetição do indébito: a atual posição do STJ. Repetição do indébito tributário. CEZAROTI, Guilherme (Coord.). São Paulo: Quartier Latin, 2005, p. 153-163.

. Repetição do Indébito, Compensação e Ação Declaratória. In: Machado, Hugo de Brito (Coord.). Repetição do Indébito e Compensação no Direito Tributário, São Paulo: Dialética; Fortaleza: Instituto Cearense de Estudos Tributário, 1999, p. $122-145$.

Trouw, Ernesto Johannes. Os juros incidentes sobre a repetição do indébito. In: CeZaroti, Guilherme (Coord.), Repetição do Indébito Tributário. São Paulo: Quartier Latin, 2005, p. 321 - 352.

VANONI, Ezio. Natureza e Interpretação das Leis tributárias. Rio de Janeiro, Financeiras, 1932. 
VARGAS, Angelo Miguel de Souza. O controle de constitucionalidade e suas implicações na repetição de indébito tributário. Revista Tributária e de Finanças Públicas - v. 13 n. 63 jul./ ago. 2005, p. 100-125.

VAZQUeZ, Rafael Navas. La Devolución de los Ingresos Tributarios. Madrid: Editorial Civitas S.A., 1992.

Valverde, Gustavo Sampaio. Coisa Julgada em Matéria Tributária. São Paulo: Quartier Latin, 2004.

Veloso, Zeno. Controle jurisdicional de constitucionalidade. 2. ed. Belo Horizonte: Del Rey, 2009.

Velloso, Andrei Pitten. A temerária modulação dos efeitos da pronúncia de inconstitucionalidade em matéria tributária. Revista Dialética de Direito Tributário - n. 157 out. 2008, p. 7-16.

Velloso, Renato Belo Vianna. Repetição do indébito tributário e a súmula vinculante 8. Revista do Tribunal Regional Federal da $1^{\text {a }}$ Região - v. 22 n. 3 mar. 2010 Brasília: TRF 1. Região, 2010, p. 31-46.

Venosa, Sílvio de Salvo. Direito Civil II - Teoria Geral das Obrigações e teoria geral dos contratos. 6. ed. São Paulo: Atlas, 2006.

Vilanova, Lourival. Causalidade e Relação no Direito. 4. ed. São Paulo: Revista dos Tribunais, 2000.

Wambier, Teresa Arruda Alvim. Nulidades do Processo e da Sentença. 5. ed. São Paulo: Editora Revista dos Tribunais, 2004.

XAVIER, Alberto. Regime Constitucional das Isenções e Incentivos Fiscais às exportações: o caso do ICMS. Do Direito à utilização integral de Saldo acumulado de créditos de ICMS como corolário da imunidade das exportações. In: TORRES, Heleno Taveira (Coord.). Tratado de Direito Constitucional Tributário - Estudos em Homenagem a Paulo de Barros Carvalho. São Paulo: Saraiva, 2005, p. $597-623$.

ZaVAscki, Teori. Eficácia das Sentenças na Jurisdição Constitucional. São Paulo: Revista dos Tribunais, 2001.

. Embargos à execução com eficácia rescisória: sentido e alcance do art. 741, parágrafo único do CPC. Revista de Processo, n. 125, ano 30, junho de 2005, p. 77-91. 